\title{
Evaluation of a PV-TEG Hybrid System Configuration for an Improved Energy Output: A Review
}

\author{
Umar Abubakar Saleha, ${ }^{a}$, Muhammad Akmal Joharb, Siti Amely Jumaata, \\ Muhammad Nazri Rejabb,d, Wan Akashah Wan Jamaludin ${ }^{b}$
}

\author{
${ }^{a}$ Faculty of Electrical and Electronics Engineering, Universiti Tun Hussein Onn Malaysia, Johor, Malaysia \\ ${ }^{b}$ Faculty of Mechanical and Manufacturing Engineering, Universiti Tun Hussein Onn Malaysia Johor, Malaysia
}

${ }^{c}$ Centre for Atmospheric Research, National Space Research and Development Agency, Kogi State University Campus Anyigba, Nigeria

d Tuanku Syed Sirajuddin Polytechnic, Perlis, Malaysia

\begin{abstract}
The development of renewable energy, especially solar, is essential for meeting future energy demands. The use of a wide range of the solar spectrum through the solar cells will increase electricity generation and thereby improve energy supply. However, solar photovoltaics (PV) can only convert a portion of the spectrum into electricity. Excess solar radiation is wasted by heat, which decreases solar PV cells' efficiency and decreases their life span. Interestingly, thermoelectric generators (TEGs) are bidirectional devices that act as heat engines, converting the excess heat into electrical energy through thermoelectric effects through when integrated with a PV. These generators also enhance device efficiency and reduce the amount of heat that solar cells dissipate. Several experiments have been carried out to improve the hybrid PV-TEG system efficiency, and some are still underway. In the present study, the photovoltaic and thermoelectric theories are reviewed. Furthermore, different hybrid system integration methods and experimental and numerical investigations in improving the efficiency of PV-TEG hybrid systems are also discussed. This paper also assesses the effect of critical parameters of PV-TEG performance and highlights possible future research topics to enhancing the literature on photovoltaic-thermoelectric generator systems.
\end{abstract}

Keywords: Solar energy, photovoltaic, thermoelectric generator, hybrid photovoltaic-thermoelectric generator system, shingle

Article History: Received: $30^{\text {th }}$ Oct 2020; Revised: $5^{\text {th }}$ January 2021; Accepted: 25 $5^{\text {th }}$ January 2021; Available online: $1^{\text {st }}$ Feb 2021

How to Cite This Article: Saleh, U.A., Johar, M.A., Jumaat, S. A, Rejab, M.N., Wan Jamaludin, W.A. (2021) Evaluation of a Hybrid PV-TEG System Configuration for Enhanced Energy Performance: A Review. Int. Journal of Renewable Energy Development, 10(2), 385-400. https://doi.org/10.14710/ijred.2021.33917

\section{Introduction}

Renewable energy, such as wind, geothermal, hydroelectricity, solar, and bioenergy, is produced from natural processes that can be replenished. Such energy sources are directly or indirectly derived from the heat of the sun or from within the Earth.

Kusch-Brandt (2019) reported that renewable energy supplied an estimated power of about 181 gigawatts (GW) in 2018, representing over 26\% of global electricity production that year. Considering the world's high energy needs and the environmental consequences of fossil fuel energy generation, renewable energy is seen as a means to curtail the climate change, global warming, and other ecological emissions (Hoang et al., 2018). Furthermore, solar energy is advantageous because it is efficient, sustainable, and environment friendly (Fisac et al., 2014).

Solar energy consists of visible light and heat used as photovoltaic or solar thermal energy. It is clean, inexhaustible, limitless, and eco-friendly. These unique characteristics have motivated researchers in the energy sector to widely embrace solar energy as an alternative energy source. It is the most potent option for sustainably maintaining energy protection and meeting the global energy demand while substantially reducing greenhouse gas (GHG) emissions (Kabir et al.. 2018).

Photovoltaic (PV) systems directly convert solar energy into electricity without contributing to air pollution. While considerable progress has been made in the PV system area, much work remains unaccomplished in enhancing the overall efficiency and reducing the costs and associated risks (Sahin et al., 2020). One of the critical concerns of PV technologies is the efficiency drop caused by the PV panel's relatively high operating temperatures when exposed to high solar irradiation during the day (Jatoi et al., 2018). Therefore, the factors essential for attaining excellent performance and efficiency enhancement of the PV system depend primarily on the PV cells' cooling, through which the excess heat gets converted into additional power output and thermal energy, increasing the cells' life spans ( $\mathrm{Gu}$ et al., 2019). The efficiency is decreased by $0.25-0.5 \%$ per Celsius degree (Grubišić-Čabo et al., 2016). In increasing solar

\footnotetext{
* Corresponding author: abubakarumarsaleh1982@gmail.com
} 
Citation: Saleh, U.A., Johar, M.A., Jumaat, S. A, Rejab, M.N., Wan Jamaludin, W.A. (2021) Evaluation of a Hybrid PV-TEG System Configuration for Enhanced Energy Performance: A Review. Int. Journal of Renewable Energy Development, 10(2),385-401, doi: 10.14710/ijred.2021.33917

$\mathrm{P}$ a g e $\mid 386$

irradiation's conversion efficiency into electricity, different power generation technologies can be implemented (Mohammadnia et al., 2020a). Among the most exciting areas of study in the renewable energy sector are the advancements in energy harvesting technologies to generate more energy from solar irradiance, such as PVTEG hybrid system, which has been gaining interest (Fathabadi, 2020). In this context, the objective of the present paper is to provide a comprehensive review of different hybrid system integration methods, including experimental and numerical investigations into the improvement of PV-TEG hybrid system efficiency and the influence of critical performance parameters, such as concentration ration, thermal contact resistance, temperature coefficient, and thermoelectric figure of merit.

\section{Solar Cell}

Solar cells, which generate electricity from sunlight, constitute the critical part of a PV system. The cells form a particular semiconductor diode, such as silicon, gallium arsenide or cadmium that converts electromagnetic radiation into direct currents. (Nižetić et al., 2020). The power of PV modules is influenced by cell materials, ambient temperature, solar radiation, cell temperature, shading, and tilt angle (Jatoi et al., 2021). These factors influence the efficiency of photovoltaic modules, both alone and in conjunction with each other (Coskun et al., 2017)

\subsection{Solar Cell Modelling}

Solar cells' characteristics are modelled as in the current source (Mohammad et al., 2020; Premkumar et al., 2020). The solar cell is the main component for converting the light from the sun energy into electricity via PV effect; it, therefore, serves as a DC source.

The schematic diagram of the ideal PV cell is illustrated in Figure 1. The intensity of the output current (I) is influenced by the irradiation strength and solar cell's temperature.

The solar cell's current output is given by Equation (1 to 9) (Mohammad et al., 2020):

$$
\mathrm{I}_{\mathrm{D}}=\mathrm{I}_{\mathrm{o}}\left[\exp \left(\frac{\mathrm{q}\left(\mathrm{V}+\mathrm{IR}_{\mathrm{S}}\right)}{\gamma \mathrm{KT}_{\mathrm{C}}}\right)-1\right]
$$

where $I_{D}$ is current through the diode, $\mathrm{q}$ is the electron charge, $I_{O}$ is the reverse saturation current, $V$ is the circuit voltage, and $\mathrm{K}$ is the Boltzmann constant (Mohammad et al., 2020).

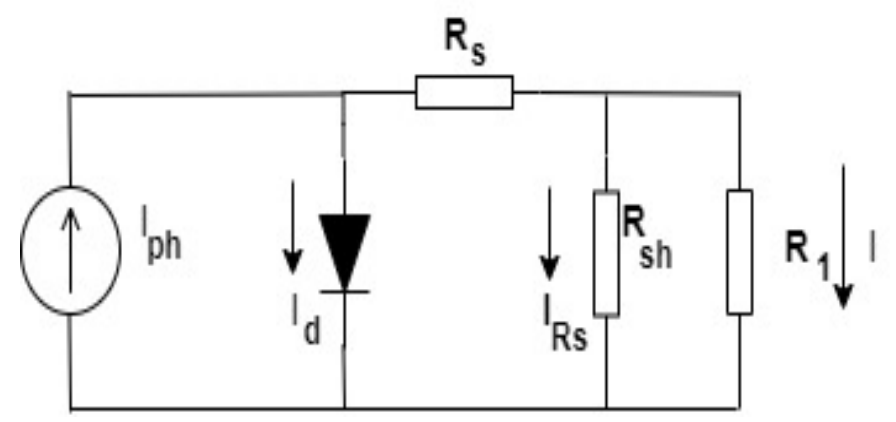

$$
\mathrm{I}_{\mathrm{O}}=\mathrm{DT}_{\mathrm{ab}}^{3} \exp \frac{\mathrm{q} \varepsilon \mathrm{G}}{\mathrm{AKT}_{\mathrm{ab}}}
$$

Where $T_{a b}$ is the temperature coefficient, D is the diode diffused factor, $\mathcal{E} G$ is material bandgap, and $\mathrm{A}$ is the area of the solar cell. Solar cells are generally arranged in parallel and series depending on the system requirements. The voltage and current of a solar cell generator can be obtained using Equation (3) (Fisac et al., 2014):

$$
V_{g}=I_{g} R_{s} \frac{N_{S}}{N_{P}} l_{n}\left(1+\frac{N_{P} I_{P h}-1}{N_{P} I_{O}}\right)
$$

where $N_{S}$ and $N_{P}$ are the numbers of series and parallel cells, respectively, $R_{S}$ is the series resistance, and $I_{P h}$ is the photocurrent of the solar cell proportional irradiance (Mohammad et al., 2020).

$$
\mathrm{I}_{\mathrm{g}}=\mathrm{I}_{\mathrm{Ph}}-\mathrm{I}_{\mathrm{O}} \exp \left(\frac{\mathrm{qV}_{\mathrm{g}}}{\mathrm{K}_{\mathrm{T}}}-1\right)
$$

where $I_{O}$ is as in Equation $1, I_{S C}=I_{P h}$ at $V_{g}=0$, which varies with the open-circuit voltage $\left(V_{O C}\right)$ obtained at $I g=0$ and irradiance of the solar cell (Mohammad et al., 2020) thus,

$$
\mathrm{V}_{\mathrm{O}}=\frac{\mathrm{K}_{\mathrm{T}}}{\mathrm{q}} \mathrm{l}_{\mathrm{n}}\left[\frac{\mathrm{I}_{\mathrm{Ph}}}{\mathrm{I}_{\mathrm{O}}}\right]
$$

The cell maximum power output is given as,

$$
\begin{aligned}
& \frac{\mathrm{d}\left(\mathrm{V}_{\mathrm{g} x I_{\mathrm{g}}}\right)}{\mathrm{dt}} \\
& \mathrm{V}_{\mathrm{mp}}=\mathrm{V}_{\mathrm{OC}}-\frac{\mathrm{KT}}{\mathrm{q}}\left[\frac{\mathrm{V}_{\mathrm{mp}}}{\mathrm{kt} / \mathrm{q}}+1\right]
\end{aligned}
$$

Fill factor (FF) can be expressed as

$$
\mathrm{FF}=\frac{\mathrm{v}_{\mathrm{mp}} \mathrm{XI}_{\mathrm{mp}}}{\mathrm{V}_{\mathrm{OC}} \mathrm{XI}_{\mathrm{SC}}}
$$

The efficiency of the PV can be expressed as:

$$
\eta_{P V}=\frac{F_{F x V_{O C} X I_{S C}}}{P_{\text {in }}}
$$

where the power of the incident radiation is represented as $P_{\text {in }}$.

\section{Thermoelectric Generator}

Thermoelectric generators can use the Seebeck effect shown in Fig. 3a to produce electricity from the thermal energy. According to the Seebeck effect, once a delta $\mathrm{T}(\Delta T)$ is established across the TEG consisting of $p$ and $n$-type materials, a potential difference $(\Delta \mathrm{V})$ can be created $(\mathrm{Li}$ et $a l ., 2010)$ and expressed by Equation 10:

$$
\alpha=\Delta \mathrm{V} / \Delta \mathrm{T}
$$

where $\alpha, \Delta V$ and $\Delta T$ are the Seebeck coefficient, generated voltage and the temperature difference across the TEG, respectively.

Conversely, applying a current through the two junctions of a thermoelectric couple creates a temperature difference, as discovered by a French physicist Jean Charles Peltier. called the Peltier effect; it is shown in Fig. 3b (Li et al., 2010). This effect is essential for a TEG's performance as a coolant (Shittu et al., 2019).

Fig. 1. Photovoltaic cell model 


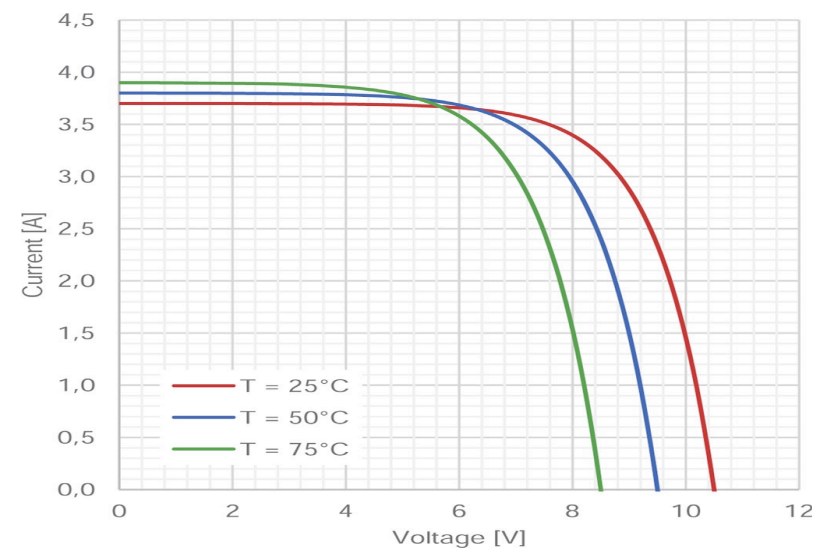

Fig. 2. Temperature Influence on a photovoltaic cell (Fisac et al., 2014).

A thermoelectric device (TE) is capable of converting heat into electricity. A thermoelectric cooler (TEC) can transfer heat out of the system (cooling) by applying an electrical current. A thermoelectric device is applicable in refrigeration and green energy generation, as shown in Fig. 3 (Elsheikh et al., 2014).

\subsection{Thermoelectric Generator Modelling}

The efficiency of the thermoelectric generator is given in Equation (11) (Shittu et al., 2019):

$$
\eta=\frac{\text { Load Energy }}{\text { The energy of the hot junction }}
$$

By maintaining appropriate properties of thermoelectric material with minimal contact resistance, the efficiency can be described as follows:

$$
\eta_{\text {teg }}=\frac{I^{2} R}{\alpha \mathrm{IT}_{\mathrm{H}}}=\frac{\mathrm{T}^{2} \mathrm{R}}{\mathrm{K}\left(\mathrm{T}_{\mathrm{H}}-\mathrm{T}_{\mathrm{C}}\right)^{-1} / \mathrm{2}^{\mathrm{I}^{2} \mathrm{R}}}
$$

where $I, R, T_{H}, T_{C}$ represent the thermoelectric generator current, series resistance, and hot and cold side temperatures, respectively.

The maximum TEG efficiency is expressed in Equation (13)

$$
\eta_{\max }=\eta_{\mathrm{C}}=\frac{\sqrt{1+\mathrm{ZT}}-1}{\sqrt{1+\mathrm{ZT}}+\frac{\mathrm{T}_{\mathrm{C}}}{\mathrm{T}_{\mathrm{H}}}}
$$

where $\eta_{C}$ represents the Carnot efficiency expressed as (Shittu et al., 2019):

$$
\eta_{C}=\frac{T_{H}-T_{C}}{T_{H}}
$$

Thermoelectric cooler efficiency is expressed as its coefficient of performance (COP), which is given in Equation 15 (Shittu et al., 2019),

$$
\mathrm{COP}=\frac{\text { Heat absorbed }}{\text { Electrical power input }}=\frac{\alpha \mathrm{IT}_{\mathrm{C}}-\mathrm{K}\left(\mathrm{T}_{\mathrm{H}}-\mathrm{T}_{\mathrm{C}}\right)}{\alpha \mathrm{I}\left(\mathrm{T}_{\mathrm{H}}-\mathrm{T}_{\mathrm{C}}\right)+\mathrm{I}^{2} \mathrm{R}}
$$

where $I, R, T_{H}, T_{C}$ are the same as in Equation (12) (Shittu et al., 2019),

The maximum cooling power current (I) is given in Equation (16):

$$
\mathrm{I}=\frac{\alpha \mathrm{T}_{\mathrm{C}}}{\mathrm{R}}
$$

The maximum coefficient of performance is:

$$
\operatorname{COP}_{\max }=\frac{T_{C}\left[(1+Z T)^{2}\right]-\frac{T_{C}}{T_{H}}}{\left(T_{H}-T_{C}\right)\left[(1+Z T)^{2}\right]+1}
$$

The thermoelectric figure of merit (ZT) defines the optimum output coefficient of TEG.
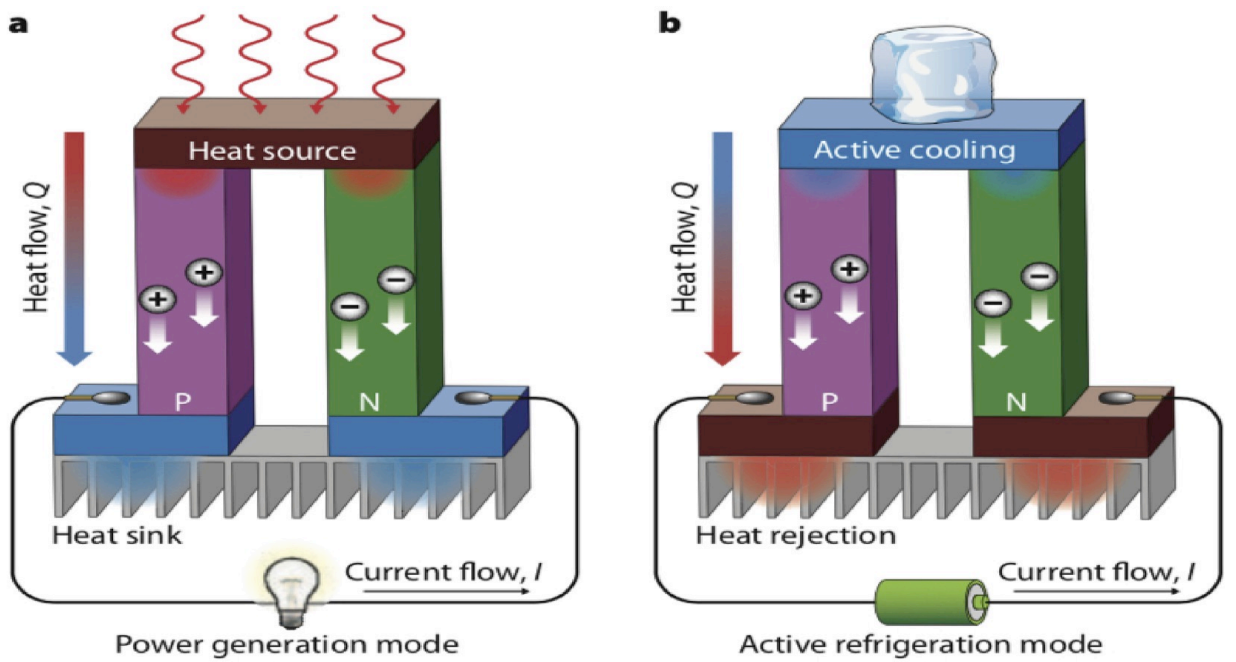

Fig. 3. A thermoelectric Device. (a) as an energy generator (b) a coolant ( Li et al., 2010). 
Citation: Saleh, U.A., Johar, M.A., Jumaat, S. A, Rejab, M.N., Wan Jamaludin, W.A. (2021) Evaluation of a Hybrid PV-TEG System Configuration for Enhanced Energy Performance: A Review. Int. Journal of Renewable Energy Development, 10(2),385-401, doi: 10.14710/ijred.2021.33917

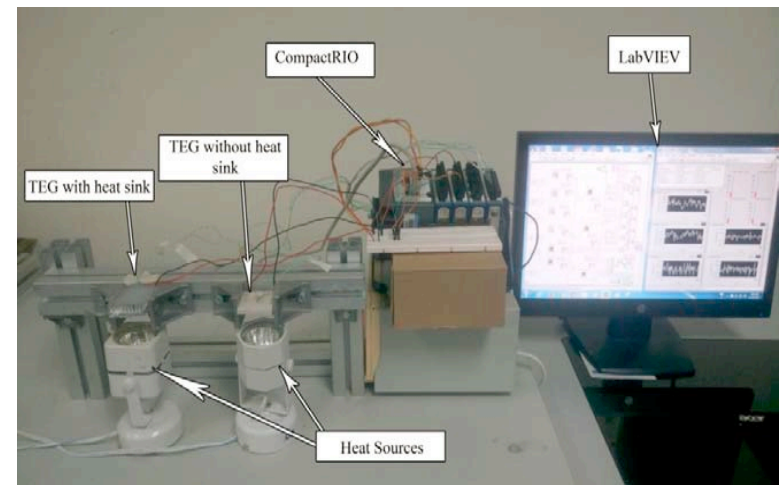

Fig. 4. Experimental setup of the TEG measurement. (Johar et al., 2017)

\subsection{Application of Thermoelectric Generator}

Thermoelectric generators are used in a broad range of applications, such as micropower generation (Aravind $e t$ al., 2020), wearable sensors (Lund et al., 2020), automotive waste heat recovery (Patel \& Patel, 2020; Kumar et al., 2020), wireless sensor network (Yuan et al., 2020; Lineykin et al., 2020), space power (Wang et al., 2020) and buildings (AlMusleh et al., 2020). TEGs are also used as coolers in different devices (Cai et al., 2019), such as refrigerators and air conditioners (Rostamzadeh \& Nourani, 2019; Khanmohammadi et al., 2020), as well as for unique industrial application and usage in medicine, aerospace, and military and biological weapons (Mirzakhanyan, 2005; Aljaghtham \& Celik, 2020).

\subsection{Thermoelectric Generator as Renewable Energy Sources}

Akashah et al. (2019) and Wan Jamaludin et al. (2020) conducted an experimental investigation to analyze the feasibility of using a thermoelectric generator as a renewable energy source. A 40 x 40 x 3.5 mm TEC1-12706 was used for the study. National Instrument (NI-CRIO 9014) was employed to acquire the temperature, current, and voltage measurements. Halogen lamps were used as the heat source for the TEG, and LabView software was used for data display, as shown in Fig. 4. The results showed that the two TEGs produced $416.82 \mu \mathrm{W}$ power when connected in series across $200 \Omega$, while they reached $100 \mathrm{Mw}$ in parallel connections at $\Delta \mathrm{T}$ of $7^{\circ} \mathrm{C}$. This was in agreement with the work of Coskun et al. (2017).

In another study, the feasibility of sustainable heat energy from a shingle utilising a TEG was evaluated for residential usages (Wan Jamaludin et al., 2020). For this evaluation, a test ring was used for TEG, and the shingle was connected to the National Instrument for DAQ, as shown in Fig. 5. The four modules of TEG in series were found to generate an average of $0.003 \mathrm{~V}$ at a load of $138 \Omega$, giving $65.22 \mathrm{uW}$ of power.

Johar et al. (2017) performed a temperature analysis in the preliminary studies of shingle-based TEG systems as a renewable energy source. The results showed that the shingle produced an input power of $10.8675 \mathrm{~W}$ at $1.5^{\circ} \mathrm{C}$, while the TEG produced $0.21 \mathrm{~W}$ at $1.75^{\circ} \mathrm{C}$.

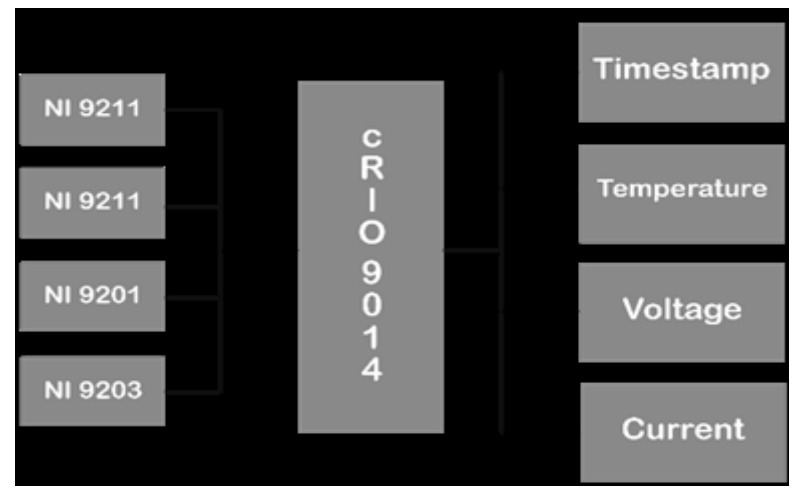

Fig. 5. Data Acquisition system for measuring voltage, current and temperature produced by TEGs (Wan Jamaludin et al., 2020)

\section{PV-TEG Hybrid System}

Various hybrid PV-TEG systems have been developed to effectively use the broad spectral region of solar energy. Radiation with energy in the bandgap region of a PV results in electricity generated by the PV-TEG hybrid system. TEG converts the energy absorbed as heat into electricity. Since TEG can act as a generator, it tends to increase the total electrical performance when incorporated into a PV-TEG system, resulting in 10\% more energy produced than a single PV solar cell, depending on the geometry, connections and the material of the TEG (Zhao et al., 2019).

The development of a hybrid PV-TEG system is, in principle, achieved in two ways. The first is the spectral splitting method for transmitting energy below the 2,500 nm cut-off wavelength to the PV and above 2,500 nm to the TEG. The second is the direct method, which connects the TEG directly to the back of the PV; the TEG uses the excess heat produced by the PV to generate additional electricity (Goldsmid et al., 1980)

Several researchers have investigated the influence of various factors, such as the cooling system (Daghigh \& Khaledian, 2018; Wu et al., 2018), concentration ration (Soltani et al., 2018; Yin et al., 2018a), system structure (Babu \& Ponnambalam, 2018; Yin et al., 2019), and contact thermal resistance (Daghigh \& Khaledian, 2018; Lamba \& Kaushik, 2018), in an attempt to determine the optimum working condition of a hybrid PV-TEG system. The majority of these researchers concentrated on the influence of solar irradiance on the hybrid PV-TEG system's performance. Their findings showed that the concentration significantly affects the hybrid system efficiency if different PV cells are used. For instance, Zhang et al., (2014) showed that a hybrid PV-TE system's performance increases when CIGS, polymer, c-Si, and p-Si PV cells with increased concentration rations are used. On the contrary, thermoelectric materials with $\mathrm{ZT} \approx 1$ improve the overall system efficiency over concentration ration. Rezania and Rosendahl (2017), and Kil et al. (2017) concluded that, using single-junction GaAs and three-junction PV cells, the system efficiency increases with an increase in the irradiance.

Shittu et al. (2019) conducted a thorough comparative evaluation of the influence of the solar concentration ratio and the flat plate heat pipe's effect as an air cooling system on minimising the temperature of the solar cell. Electrical performance analysis was conducted on PV-only, PV-TEG and PV-TEG-heat pipe systems. 


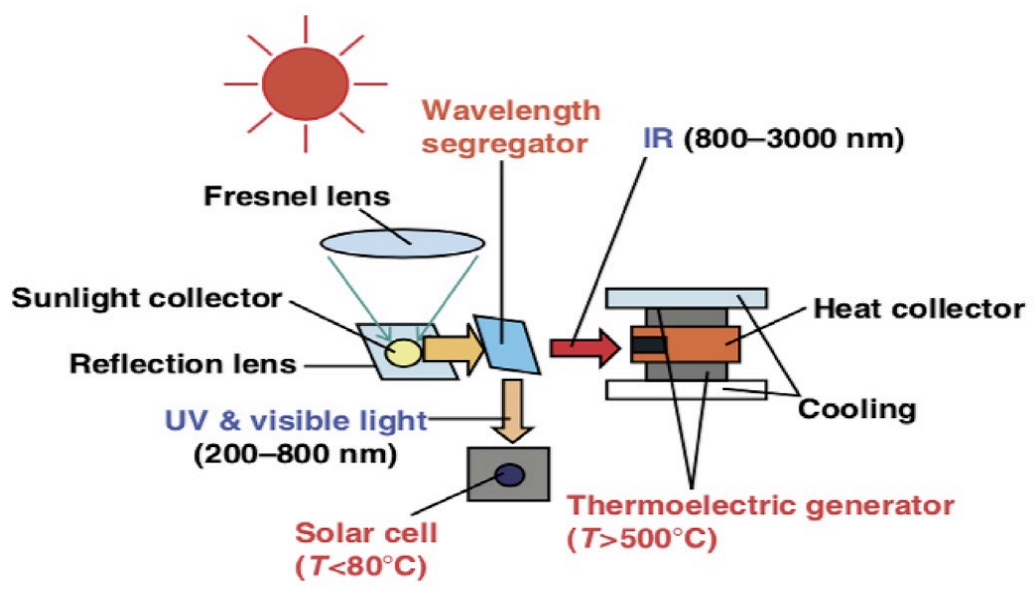

Fig. 6. PV-TEG spectrum splitting method schematics (Goldsmid et al., 1980).

Furthermore, using COMSOL 5.4 Multiphysics tools, the effect of air temperature, TEG cold junction temperature, and wind speed on PV performance and hybrid PV-TEG systems were studied. In a three-dimensional finite element analysis, the authors considered temperaturedependent thermoelectric material properties to enhance optimisation accuracy. The findings indicated that the PVTEG-heat pipe's efficiency was $61.01 \%$ and $1.47 \%$ higher than the PV-only and PV-TEG. The results further showed that a lack of sufficient cooling of the TEG could adversely harm the hybrid systems' performance.

Yin and Xuan (2019) presented an experimental optimisation for a CPV-TEG system's operating conditions, taking into account the system structure, connection modes, total input energy, and coupling characteristics of the devices. The authors stated that the hybrid CPV-TEG was evaluated at different concentration ratios with the concentrated photovoltaic (CPV) to demonstrate the effect of the optical concentration ratio on the system's efficiency. The TEG load resistance effect on power output was examined to assess the desired performance characteristics and the photovoltaic system's output voltage effect. The impacts of structural design and thermal resistance on the hybrid system's efficiency were analysed. Further, the parallel and series connections of the thermoelectric modules were investigated. The results showed a temperature difference of $28.9^{\circ} \mathrm{C}$ across the TEG when the optical concentration was increased from $74 \mathrm{~W} / \mathrm{m}^{2}$ to 217 $\mathrm{W} / \mathrm{m}^{2}$, demonstrating a substantial increase in the TEG efficiency.

Shittu (2020) presented a comprehensive threedimensional numerical analysis of four contact resistances in CPV-TEG with COMSOL 5.4 Multiphysics software. The resistivity was seen between PV and TEG, TEG and heatsink, and TEG and thermal contact resistance. For all the cases, 12 contact resistances were selected to examine the most critical one. Shittu (2020) performed a parametric optimisation to explore the optimal load resistance, thermoelectric leg height, concentration ratio, and heat convection within the system. The results indicate that all the contact resistances play a significant role in determining the system's performance. The hybrid system efficiency increases with $7.4 \%$ and $7.6 \%$. Furthermore, Shittu (2020) concluded that system thermal resistance must be minimised for effective energy harvesting.

\subsection{Spectrum splitting technique}

A PV-TE splitting system is a hybrid system consisting of the cooling system, spectrum splitting device, TE, and a PV module. The splitter reflects solar radiation at a defined wavelength in such a configuration, as shown in Fig. 6 . The TEG also reflects radiation that is wider than the wavelength cut-off point. On the other hand, radiation smaller than the wavelength cut-off point is transmitted and absorbed by the PV through the spectrum splitter (Huen \& Daoud, 2017a). It is worth noting that the TEG and PV operate separately when converting solar energy into electricity in this method; thus, the TEG does not use PV waste heat to convert energy or cool down the PV.

Yin et al. (2020) studied a concentrated tandem PV-TEG system using both experimental and theoretical models. During the experiment, the various solar concentration ratios, power outputs, and operating temperatures of both the systems were measured and recorded. Additionally, their influence on the coupling viability of various device parameters and device outputs, namely TE concentration ratio, the figure of merit, $\mathrm{TE}$ resistance, coolant temperature, efficiency, PV power, and temperature coefficient, were investigated. Finally, a few design considerations of the system were made. The findings indicated an improvement in the production from $1.38 \mathrm{~W}$ to $1.5 \mathrm{~W}$, representing an $8.7 \%$ efficiency increase with a single-junction gallium arsenide PV cell.

Shatar et al. (2019) conducted a Global Climate Performance study of an unconcentrated PV-TEG system using a panel of $100 \mathrm{~W}, 5.99 \mathrm{~A}$ as a short-circuit current and 22.45 Voc. A $5 \mathrm{~m}$ LED light was used as a load for the indoor farm. The LED was set to be switched on and off during the day at given times: between 08:00 and 22:00 in December, every 18 hours in February, and every 24 hours in March. Under the shaded area of $2.5 \mathrm{~m}^{2}$, the hybrid system was found to obtain a power output of $100 \mathrm{~W}$ without shading conditions. Shatar et al. (2019) stated that the PV was under partial shading conditions at 13:30. In December, the maximum power was observed between $15 \mathrm{~W}$ and $20 \mathrm{~W}$. Furthermore, Shatar et al. (2019) concluded that i there was a significantly low power output of about $15 \mathrm{~W}$ in February and below the same in March. Factors such as a rise in solar cell temperature, dust accumulation, and losses from wiring could also affect the output of the solar panels. The effects of weather, annual performance, 
Citation: Saleh, U.A., Johar, M.A., Jumaat, S. A, Rejab, M.N., Wan Jamaludin, W.A. (2021) Evaluation of a Hybrid PV-TEG System Configuration for Enhanced Energy Performance: A Review. Int. Journal of Renewable Energy Development, 10(2),385-401, doi: 10.14710/ijred.2021.33917

P a g e $\mid 390$

optimal working, and the seasonal conditions on the unsteady-state tandem hybrid PV-TEG system's superior performance to traditional PV systems were investigated (Yin \& Li, 2020). The findings suggested that the tandem PV-TE performed more than the PV alone in both seasons. The efficiencies of the tandem hybrid system were $27.43 \%$, compared to $26.46 \%$ of the traditional PV. However, the authors emphasised that the system's performance increase was detrimental to the system's protection and reliability. Yin \& $\mathrm{Li}$ concluded that the hybrid tandem system has a better operating temperature due to the PV cell's presence. As solar irradiance increases, the system's temperature also increases, thereby affecting the system's performance.

Li et al. (2016) conducted a simulation for generic optimisation technique on the PV-TEG hybrid system, using a spectrum splitting approach. For the simulation, Cadmium telluride, Gallium arsenide and Dye-sensitized solar cell were used. The result shows that a better hybrid system with $13.26 \%$ efficiency was produced by the amorphous silicon cell. Li et al. (2016) reported that solar TEG and solar cell spectral efficiency depended on the hybrid system's overall performance. Ju et al. (2012) performed a comprehensive investigation of a concentrated PV-TEG spectrum splitting system. Furthermore, they suggested two fundamental ways of enhancing hybrid systems' performance: improving the cooling system's enhancement and increasing the concentration ratio. The results show an optimised efficiency of $27.49 \%$, with the TEG contributing $10 \%$.

Looi et al. (2020) investigated the PV-TEG airconditioning system for residential use in a warm environment. According to Looi et al. (2020), the hybrid system was integrated with nine TEG modules to provide cooling for a $3.6 \mathrm{~m}^{3}$ volume chamber. Besides, they investigated the effect of the moisture removal rate and inputted current through a controlled experiment. The results revealed $5 \mathrm{~A}$ as the optimal current level and 0.14 L/hour as the moisture removal rate at air temperature. During the investigation, the indoor chamber's temperature was $4^{\circ} \mathrm{C}$ less than the unconditioned chamber's temperature in contrast to the air temperature. The indoor environment's humidity level was observed to be $58-83 \%$.

Additionally, the system energy consumption was 1.45 $\mathrm{kWh}$ at $5 \mathrm{~A}$ for a 12 -hour operation. Furthermore, the authors also studied the viability of $\mathrm{PT} \mathrm{A} / \mathrm{C}$ for residential cooling under the same study circumstances of temperature reduction, humidity level, and temperature of the enclosed chamber. The research findings suggested $1.67 \mathrm{COP}$ at $5 \mathrm{~A}$ with an optimum removal rate value of $0.14 \mathrm{~L} / \mathrm{h}$ and 150 to $205 \mathrm{~W}$ cooling capacity.

Yin et al. (2018b) suggested an optimised configuration for the concentrated spectrum-splitting PV-TEG system in order to maximise the solar energy in CPV-TEG spectrum splitting without sacrificing the individual's optimal configuration systems. The findings indicate that the thermoelectric ZT and the optimum cut-off wavelength of the splitter were inversely related. Yan et al. (2018) analysed the efficiency through computational simulation of the PV-TEG spectrum-splitting system. The thermoelectric generator dimensionless current and the solar cell voltage were also studied. The findings show improved system performance by $2.67 \%$ and $2.19 \%$, respectively, at 30 and above concentration.
Bjørk and Nielsen (2018) analysed the optimal mathematical efficiency of a concentration-free PV-TEG system. They adopted an empirical approach during the research, and the results showed that a peak efficiency gain of $1.8 \%$ could be achieved using spectrum splitting in the hybrid system.

Simulating a hybrid PV-TEG using 127 TEG numbers (Yin et al., 2019) revealed that the system's average output power was $12.99 \mathrm{~W}$ and $13.37 \%$ higher at $600 \mathrm{~W} / \mathrm{m}^{2}$ than the PV alone with a concentration ratio of $3 \mathrm{~W} / \mathrm{m}^{2}$. Yin et al., (2019) noted that PV, TE, and hybrid PV-TEG systems' output power reduces when the concentration is one and five. The system's output power decreases from $0.7 \%$ to $4.78 \%$ at $700 \mathrm{~W} / \mathrm{m}^{2}$, respectively, taking into account the Thomson effect. This experiment was in line with the results of Lamba and Kaushik (2016), who showed that the PV-TEG hybrid system's power output decreases at 720 $\mathrm{W} / \mathrm{m}^{2}$.

Rezania and Rosendahl (2017) conducted additional research on the P-TEG hybrid-concentrated system with the latest TEG of $\mathrm{ZT} \approx 1$. The study showed that the CPVTEG system has improved efficiency compared to the CPV system, as shown in Fig. 7. Applying the energy equation to the first law of thermodynamics, Cai et al. (2020) analysed the effect of the number of TEGs, air temperatures, and solar irradiance on the hybrid CPV-TEG output power. To improve the TEV system's cooling and heating efficiency, the TEC number and input current were carefully varied. An incorporated numerical and mathematical technique was eventually developed to align the TEV power input with the CPV-TEG power output. The modelled findings showed that when the thermoelectric cooler input currents for cooling and heating modes are not more than 2.5 A and $2.8 \mathrm{~A}$, respectively, the CPV-TEG output power could meet the energy demand of the TEV system. The system's minimum energy performance was $0.24 \%$ for the CPV-TEG and $1.67 \%$ for the TEV with CPV-TEG in the winter heating mode, which was much better than those of the summer cooling mode.

The results also show that the CPV-TEG system's performance depends heavily on the physical parameters, like the air temperature in the environment, and the number of TEGs. The power output for $\mathrm{C}=5$ rises to 967 $\mathrm{W} / \mathrm{m}^{2}$, decreasing with an increase in solar irradiance. The results further show that the system achieves a maximum power output at $154.29 \mathrm{~W}$.

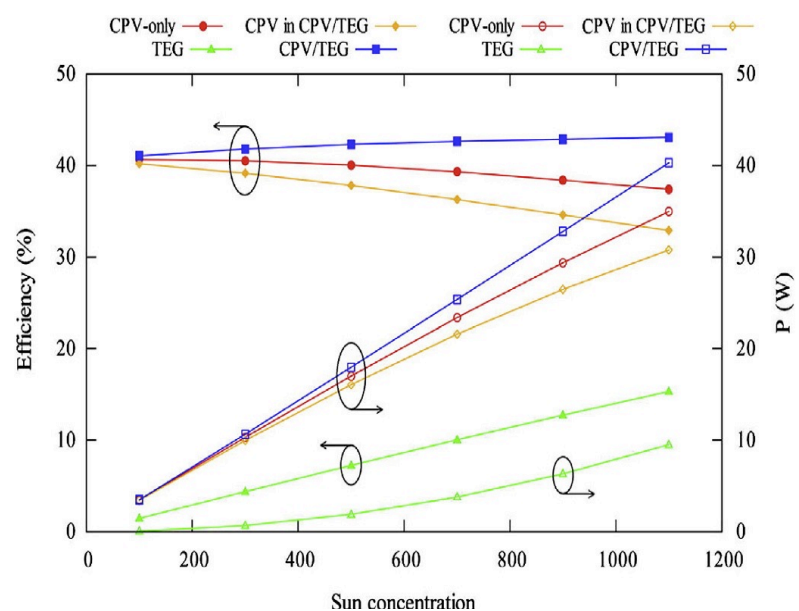

Fig. 7 Variation of sun concentration in system efficiency (Rezania \& Rosendahl, 2017). 


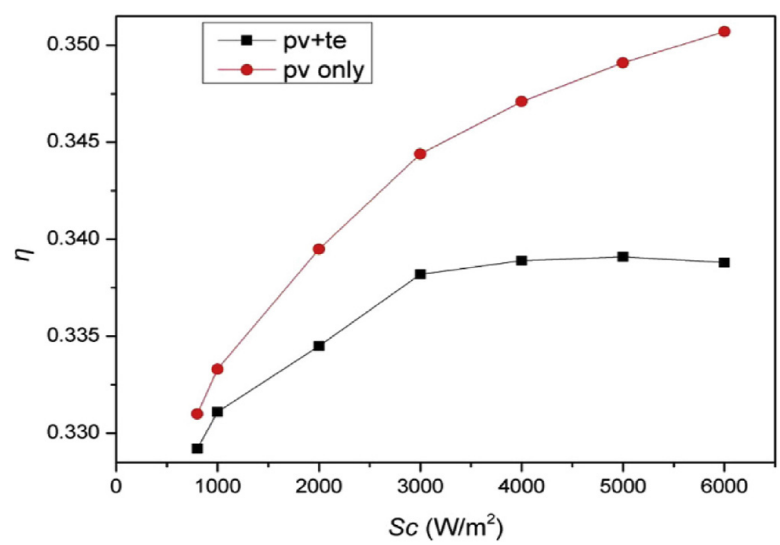

Fig. 8 Variation of the Hybrid and PV system (Lin et al., 2014).

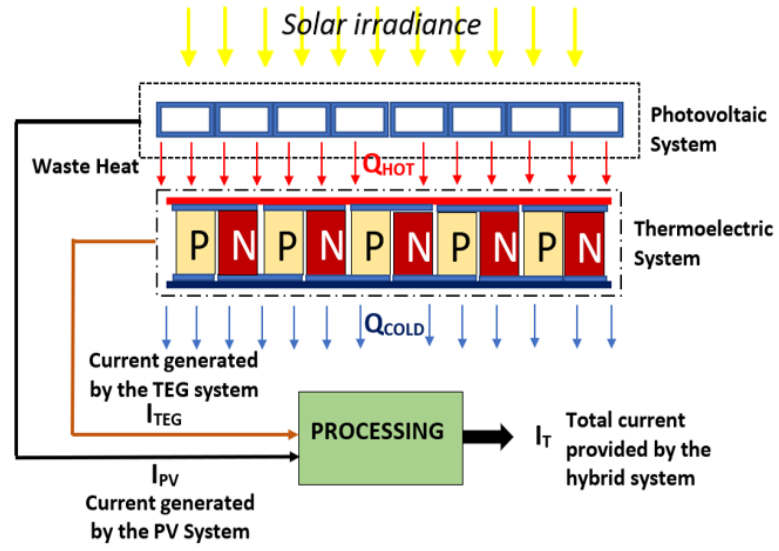

Fig. 9 Direct coupling integration of PV-TEG (Fisac et al., 2014).

Cai et al. (2020) concluded that, at $1.3 \mathrm{~A}, 1.68 \mathrm{~A}$, and 2.62 , the maximum exergy efficiency was $5.33 \%, 3.17 \%$ and $0.75 \%$, respectively, in summer mode. Mahmoudinezhad et al. (2018) performed a theoretical investigation of a low solar simulator CPV-TEG hybrid system. The findings suggested that the simulation's outcome agreed with the laboratory results, which showed that the CPV-TEG's optimum efficiency was $35.33 \%$. The variation of the PVTEG system with PV only is shown in Fig. 8.

Singh et al. (2018) presented the thermodynamic evaluation of a hybrid CPV-TEG cogenerated device's irreversibility and the optimum efficiency of a large solar spectrum in cool and warm weather conditions for a large solar spectrum. To understand its viability and assess the system's irreversibility and degradation, which is caused by the irreversible conversion of solar energy to electricity, Singh et al. (2018) modelled and simulated the hybrid system. Furthermore, they analysed the exergy and the irreversibility destruction of the system using the second law of thermodynamics. Exergy analysis was used to measure the different losses in the exergy of the system. The authors examined the influence of solar radiation's exergy up to $1000 \mathrm{~W} / \mathrm{m}^{2}$, irreversibility and energy loss, concentration ratio, Thomson coefficient, TEG temperature ratio, and current. The results indicate that as the concentration increases, the Thomson effect negatively affects the hybrid system's performance and increases its irreversibility. The hybrid system's power output also increases to $86 \%$ when the concentration rises between 1 sum and 3sum, with system exergy efficiency being $8 \%$ higher than energy efficiency. The highest number of irreversibility makes the system less efficient, as the temperature rise can lead to a substantial increase in hot sports. Singh et al. (2018) concluded that the study findings could be useful in developing a functional CPV-TEG hybrid system.

\subsection{Direct coupling technique}

This technique ensures that TEG is connected to the PV's backside with a heat sink positioned at the bottom of the TEG, as shown in Fig. 9. The photovoltaic cell absorbs the shorter wavelength in this method, while the thermoelectric generator absorbs the longer wavelength (Huen \& Daoud, 2017b). Acut el al. (2019) designed and investigated PV-TEG-WiFi Energy system for WSN usage. The system developed a power combiner circuit that utilises a cross-coupled charge pump to combine it with wind energy. The system was simulated by using $65 \mathrm{~nm}$ CMOS. The findings indicated that when a load of $500 \Omega$ was applied, $1.69 \mathrm{~mW}$ was produced, achieving $69 \%$ efficiency. A highly efficient CPV-TEG was analysed and presented by Kil et al. (2017); they demonstrated a hybrid CPV-TEG using a conventional TEG module and a single-junction GaAs-solar cell to form a concentrated hybrid system based on the direct coupling method. The experiment was under 50 suns concentration. The heat flow was controlled using TEG in the system. The results showed a $3 \%$ improvement in the overall efficiency of the hybrid system. Kil et al. (2017) concluded that the Peltier effect was crucial in achieving better efficiency.

The preliminary experiment on a novel PV-TEG system was presented in the sunny season (Shittu et al., 2019). Shittu et al. (2019) attached the PV modules to the top surface of an MCHP, and, as shown in Figure 10, the TE modules were mounted to the bottom condenser layer. The solar energy falls to the surface of the PV in this model. In contrast, the PV's thermal energy is transported to the MCHP through the heat exchanger in the MCHP. Also, by condensation of the heat exchanger through evaporation, heat is released and passed to the TEG, creating a delta $\mathrm{T}$ that converts thermal energy through the Seebeck effect to electrical power. Furthermore, air cooling cools the TEG and the cooling structure. The findings suggest that the proposed design has a $14.0 \%$ efficiency gain, producing a better electrical output than the PV.

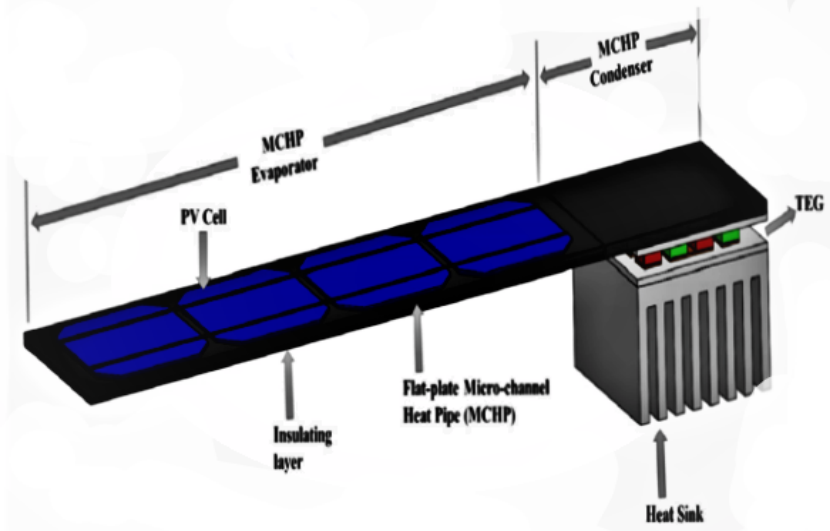

Fig. 10. Pictorial representation of PV-TE-MCHP ( Shittu et al., 2019) 
Citation: Saleh, U.A., Johar, M.A., Jumaat, S. A, Rejab, M.N., Wan Jamaludin, W.A. (2021) Evaluation of a Hybrid PV-TEG System Configuration for Enhanced Energy Performance: A Review. Int. Journal of Renewable Energy Development, 10(2),385-401, doi: 10.14710/ijred.2021.33917

$\mathrm{P}$ a g e $\mid 392$

A new CPV-TEG system incorporated into PCM to form PV-PCM-TEG has been developed by Cui et al. (2016). PCM has been used to minimise the fluctuation in temperature between the modules of PV and TEG. Four PV cells-CIGS, c-Si, GalnP/InGaAs/Ge, and single-junctionwere used for the investigation. The authors obtained the optimal operating temperature in the system. They stated that the hybrid system with PCM as a buffer is preferred to the single PV or PV-TEG system in terms of efficiency.

Using a phase change material as an absorber plate connected with a PV-TEG to develop a PV-TEG-PCM unit, a transient simulation of a PV-TEG system was carried out (Motiei et al., 2019). The PCM saved a considerable amount of heat energy during the phase change operation and provided increased storing space. Ultimately, this configuration manages the system's temperature, decreases PV temperature, increases the delta $\mathrm{T}$ through TEG, and enhances its efficiency. For the days in the warm and cold season, two-dimensional modelling was accomplished. In the simulation, ambient air temperature, wind speed, heat loss, and concentration are included. The results were better than the PV alone and PV-TEG system for hybrid performance. Motiei et al. (2019) further investigated the thickness and the melting point of the PCM and concluded that the optimum thickness and material depend on the environmental situation. Hajji et al. (2017) presented an analysis based on advanced PV-TEG hybrid system with a high-performance output, utilising avant-garde heat exchanger tracking. Hajji et al. (2017) placed a concentrator between TEG and the PV by avoiding any direct contact of the three elements. The results show a temperature of an irradiance flux of $53^{\circ} \mathrm{C}$ at an irradiance of around $1000 \mathrm{~W} / \mathrm{m}^{2}$ of the PV.

Sark (2011) proposed an active thermal management technique to develop a PV-TEG hybrid system for improved electrical efficiency, using a direct coupling approach. Two scenarios have been introduced for Utrecht in the Netherlands and Malaga in Spain. The total electricity output was also calculated by utilising weather data from both locations. The author also provided efficiency improvement forecasts based on potential thermoelectric materials to be produced. The result is shown in Fig. 10 .

Liu et al. (2020) performed a hybrid PV-TEG system efficiency assessment with light and heat control. The hybrid system was developed with various glass cover coating to investigate the performance improvement, as shown in Figure 12. The results in Figure 13 illustrate that the selective coating increased the system's power output by around $0.8 \%, 1.3 \%$, and $14 \%$, respectively. The impact factor analysis also shows that the effect of moisture content on system performance is less significant. In contrast, the concentration ratio, wind speed, and ambient temperature have a vital role in power generation. The $\mathrm{SiO}_{2}$ coating has at least three years' payback period. The values of selective coatings and anti-reflective coatings are roughly five years and not up to four years, respectively. Liu et al. (2020) concluded that their work would give new ways of improving the system's efficiency.

Rejeb et al. (2020) conducted an optimisation study on a solar hybrid CPV-TE system, using COMSOL Multiphysics software centred on the finite element approach. The programme was used to perform threedimensional numerical analysis. The results showed that the system produced an efficiency of $7.8 \%$. Using ANOVA, a response surface statistical method, the numerical model results were analysed with a quadratic regression tool. The results showed that the coefficient of determination $\left(R^{2}\right)$ is 0.9945 for electrical efficiency. Furthermore, a simple polynomial numerical algorithm was developed to project and optimise the system's electrical performance, focusing on the four input variables investigated. The proposed method's maximum electrical efficiency was $17.448 \%$ at 2 $\mathrm{K} \Omega$ electrical load resistance, $229.698 \mathrm{~W} / \mathrm{m}^{2}$ irradiances, $3.083 \mathrm{~mm}$ TE module height value, and 303 to $353 \mathrm{~K}$ ambient temperature values for optimum operating parameters.

A double cooling system with a solar PV-TE collector in three modes was experimentally and theoretically investigated (Daghigh \& Khaledian, 2018) in Sanandaj, Iran. A single and double evaporator cooling system without a PV collector, a network-connected in a series arrangement with a PV-TE-air system and a compression was investigated in three modes in July 2016. Twenty-two (22) TEG modules were tested in the PV-TE mode, according to Daghigh and Khaledian (2018). Eleven TEG were grouped in parallel out of the 22 , while the other 11 were in series.
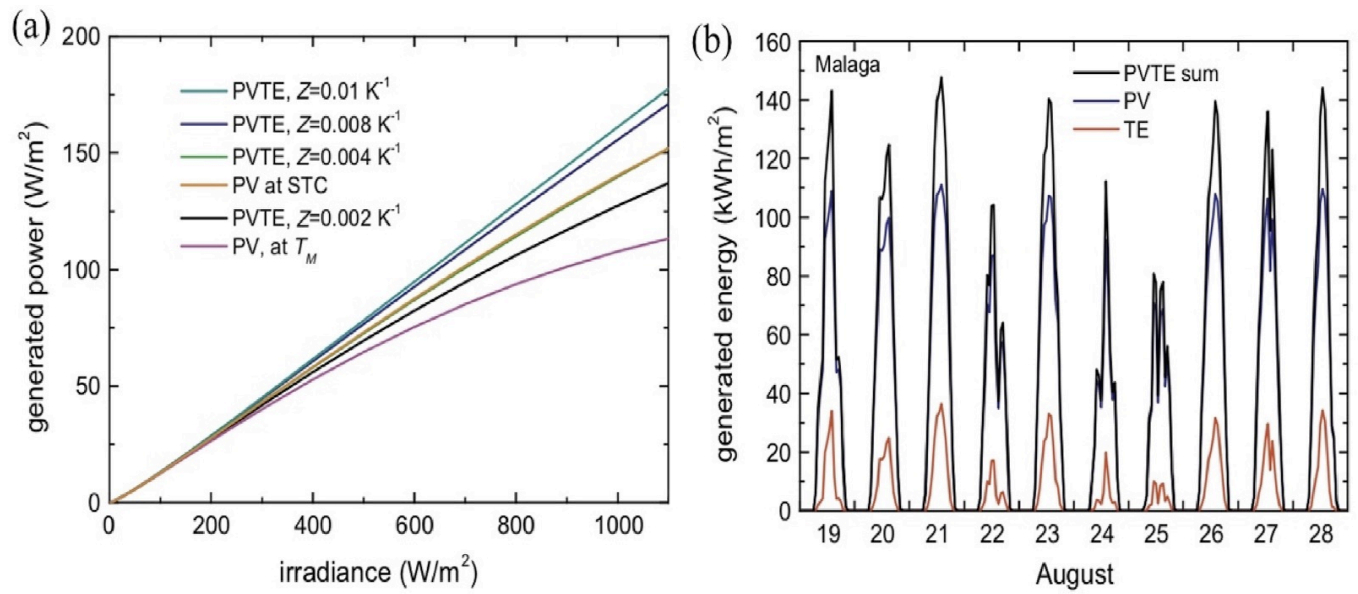

Fig. 11 Power Output of the hybrid system (a) power generated using four (ZT) values and (b) total power of Malaga, Spain (Sark, 2011). 


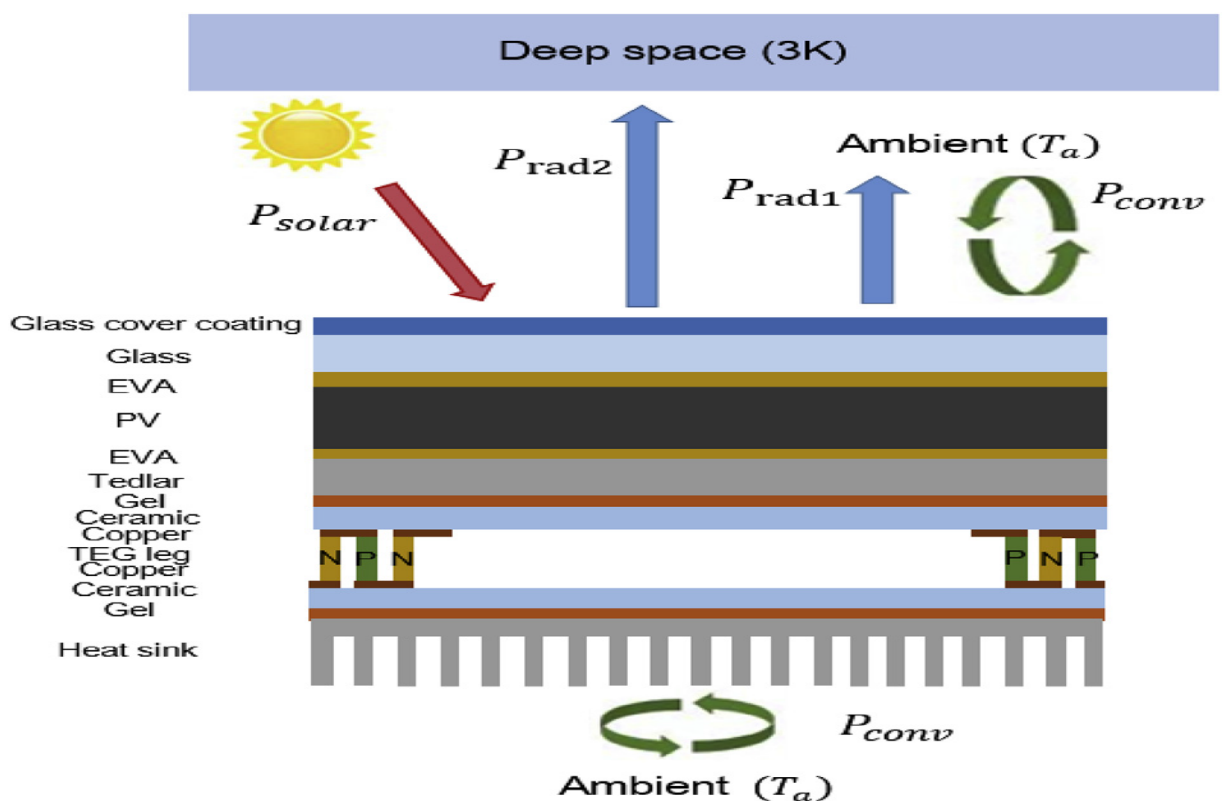

Fig. 12. Developed hybrids PV-TEG system with glass cover coatings (Liu et al., 2020)

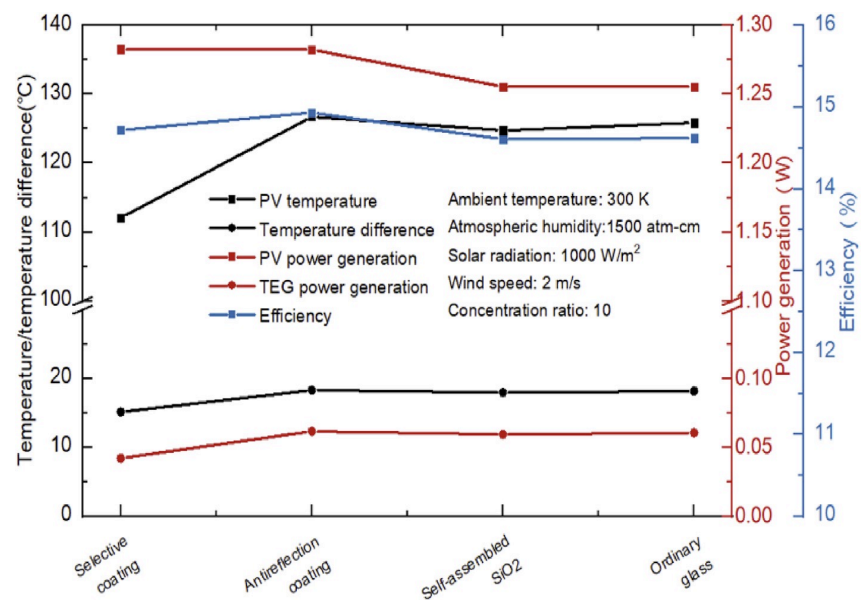

Fig. 13. Performance of Power generation by hybrid PV-TEG system using various glass cover coatings (Liu et al., 2020)

The findings showed that, in the single-evaporator cooling and the hybrid double-evaporator cooling systems with the PV-TE collector, the compressor's power consumption and performance coefficients were $3,754 \mathrm{~kW}, 1,353 \mathrm{~kW}, 1,332$ $\mathrm{kW}$, and 3.69, respectively. They signified a positive impact of the PV-TE system on the compressor's energy consumption and COP. Their results also showed that the overall electrical performance and power output for a TEG device is $0.038 \mathrm{~W}, 0.063 \mathrm{~W}, 0.063 \mathrm{~W}, 1.12 \mathrm{~W}$, and $1004 \mathrm{~W} / \mathrm{m}^{2}$ solar irradiance for the evaporator and the PV-TE-air system, respectively. The PV collector's electrical power generation rates were $0.11 \mathrm{~W}$ and $0.119 \mathrm{~W}$ for the two modes. These values reflect the positive refrigeration effect of the TEG device with an improved collector electrical efficiency.

An innovative technique of the different geometric placement of TEG within the concentrated systems with a delta of $50{ }^{\circ} \mathrm{C}$ and $200^{\circ} \mathrm{C}$ was suggested by Chávez-Urbiola et al. (2012). The optimised PV-TEG system has a higher thermal power ratio to electrical power output than the hybrid PV-T. The TEG's efficiency is dependent on solar irradiance. However, PV performance mostly relies on a linear solar irradiance function. For a $\mathrm{T}$ of $150{ }^{\circ} \mathrm{C}$, the efficiency of the TEG is $4 \%$.

Further research of the hybrid PV-TEG system's design optimisation was carried out using a direct coupling technique (Lin et al., 2014; Makki et al., 2016). The hybrid PV-TEG's overall performance was measured in the design for over twenty-four hours to observe any effects on the hybrid system's performance by solar radiation variance overtime. The findings showed a $16.7 \%$ efficiency improvement, which is much bigger than the PV alone. The results correspond with $\mathrm{Li}$ et al. (2019) and Babu and Ponnambalam (2017).

$\mathrm{Gu}$ et al. (2019) proposed a numerical model to evaluate a PV-TEG hybrid system's performance. The system design focused on the thermal resistance theory of PV panel, and the TEG. According to the authors, the system's electrical and thermal output was achieved through an iterative analysis of temperature measurement, connecting power generation with heat coupling. Additionally, during the numerical simulation, different heat losses and environmental factors were considered, and the PV alone was determined to be a comparative benchmark. The impact of the temperature coefficient and concentration ratio on system performance was also studied. The results suggest that a lower temperature coefficient and a higher PV cell concentration ratio are desirable for the hybrid system.

Furthermore, a sensitivity analysis of each component's thermal resistance within the hybrid system was performed and the relevant design parameters analysed. Gu et al argued that the heat sink was found to influence the hybrid system's thermal resistance to the cooling system, proposing that limiting the cooling system's thermal resistance would be the most effective strategy for improving its performance. Finally, it was concluded that the hybrid system generated 1.24 to $2.85 \%$ efficiency, which was higher than that of the PV alone 
P a g e |394

Table 1

Summary of PV-TEG system related work

\begin{tabular}{|c|c|c|c|}
\hline Author & Application & Results & Remark \\
\hline Zhang et al. (2020) & $\begin{array}{l}\text { Commercial monocrystalline PV cell and Bi2Te3 were used in a } \\
\text { controlled experiment based on the direct coupling using the Alumina } \\
\text { layer between the PV and TEG. }\end{array}$ & $\begin{array}{l}\text { The PV in the integrated system achieved } 14.9 \% \text { output } \\
\text { power, which was higher than the PV alone under } 350 \mathrm{~mW} \\
\mathrm{~cm}^{2} \text { and } 15{ }^{\circ} \mathrm{C} \text { using a } 16.1 \mu \mathrm{m} \text { alumina, and the system } \\
\text { achieved } 7.56 \% \text {, which was more than the approach using } \\
18.8 \mu \mathrm{m} \text { alumina layer. }\end{array}$ & Controlled experiment \\
\hline Wang et al. (2020) & $\begin{array}{l}\text { A numerical simulation was used to compare the CPV-TEC with CPV- } \\
\text { TEG using thermodynamic and exert economic comparison }\end{array}$ & $\begin{array}{l}\text { An increase in TEG operating current of about } 0.27 \text { A could } \\
\text { convert the TEG to TEC with a minimal system exergy price } \\
\text { of } 0.263 \$ / \mathrm{kWh}, 0.148 \$ / \mathrm{kWh}, 0.113 \$ / \mathrm{kWh}, 0.266 \$ / \mathrm{kWh} \text {, } \\
0.152 \$ / \mathrm{kWh} \text {, and } 0.118 \$ / \mathrm{kWh} \text { for the system, respectively. }\end{array}$ & $\begin{array}{l}\text { Difference between CPV-TEC } \\
\text { and CPV-TEG using numerical } \\
\text { analysis }\end{array}$ \\
\hline Rodrigo et al.(2019) & $\begin{array}{l}\text { A triple-junction } \mathrm{GaInP} / \mathrm{GaInAs} / \mathrm{Ge} 3 \mathrm{~mm} \times 3 \mathrm{~mm} \text { solar cell was } \\
\text { thermally coupled with a TEG through simulation. }\end{array}$ & $\begin{array}{l}\text { A maximum predicted efficiency of } 39.2 \% \text { at } 800 \mathrm{x} \text { with a cost } \\
\text { reduction of } 46.0 \% \text { at } 1900 \mathrm{x} \text { was achieved. }\end{array}$ & Simulation \\
\hline Lakeh et al.(2019) & $\begin{array}{l}\text { The coupling was done through simulation using the direct coupling of } \\
\text { the PV with Bi2eTe } 3 \text { TE module non-concentration. }\end{array}$ & $\begin{array}{l}\text { The results show that an increase in solar irradiance can } \\
\text { increase the PV-TEG utilisation. }\end{array}$ & Solar irradiance and analysis \\
\hline Xu et al. (2018) & $\begin{array}{l}\text { The TEG module and the PV were arranged using a direct coupling } \\
\text { method with the TEG placed at the PSC's carbon side. }\end{array}$ & $\begin{array}{l}\text { The hybrid system achieved a } \mathrm{V}_{\mathrm{oc}} \text { of } 1.29 \mathrm{~V} \text { and } 20.3 \% \text { power } \\
\text { output using the irradiation of } 100 \mathrm{~mW} \mathrm{~cm}-2 \text {. }\end{array}$ & Controlled experiment \\
\hline Keser et al. (2019) & $\begin{array}{l}\text { Numerical analysis and optimisation were performed based on direct } \\
\text { coupling approach. }\end{array}$ & $\begin{array}{l}\text { This approach could improve the solar cell efficiency by } 21.9 \% \\
\text { and the total hybrid efficiency by } 2.95 \% \text { via the substrate } \\
\text { material with thermal conductivity of } \mathrm{k}=0,01 \mathrm{~W} / \mathrm{mK}\end{array}$ & Numerical simulation \\
\hline Johar et al. (2017) & $\begin{array}{l}\text { TEC1-12706 with the size of } 40 \times 40 \times 3.5 \mathrm{~mm} \text { was used for this study. } \\
\text { National Instrument (NI-CRIO 9014) was employed for DAQ for the } \\
\text { temperature, current, and voltage measurements. Halogen lamps were } \\
\text { used as a heat source for the TEG. LabView software was used for data } \\
\text { display. }\end{array}$ & $\begin{array}{l}\text { Two TEGs generated } 416.82 \mu \mathrm{W} \text { of power output in series at } \\
200 \Omega \text { and } 100 \mathrm{MW} \text { when in parallel at } \Delta \mathrm{T} \text { of } 7^{\circ} \mathrm{C} .\end{array}$ & $\begin{array}{l}\text { Halogen as the source of heat for } \\
\text { the TEG }\end{array}$ \\
\hline $\begin{array}{l}\text { Wan Jamaludin et al. } \\
(2020)\end{array}$ & $\begin{array}{l}\text { Test ring was used for the TEG and the Shingle, and it was connected to } \\
\text { the National Instrument for DAQ }\end{array}$ & $\begin{array}{l}\text { Four modules of TEG in series generated an average of } 0.003 \\
\mathrm{~V} \text { at a load of } 138 \Omega \text { this gives } 65.22 \mathrm{uW} \text { of power. }\end{array}$ & $\begin{array}{l}\text { TEG attached to shingle thereby } \\
\text { giving TEG + Shingle energy }\end{array}$ \\
\hline Akashah et al. (2019) & $\begin{array}{l}\text { The TEG was attached to the backside of shingle, and heatsink was } \\
\text { placed at the TEG cold side. The system was connected to the NI for data } \\
\text { recording. }\end{array}$ & $\begin{array}{l}\text { The analysis results indicate that at } 1.5^{\circ} \mathrm{C} \text {, the shingle } \\
\text { produced an input power of } 10.8675 \mathrm{~W} \text { while the TEG } \\
\text { produced an output power of } 0.21 \mathrm{~W} \text { at the temperature } \\
\text { difference of } 1.75^{\circ} \mathrm{C} \text {. }\end{array}$ & TEG + shingle \\
\hline
\end{tabular}


Dallan et al. (2015)

direct moth was used for the PV-TE coupling. Using a monocrystalline Solar PV module with specifications of $60 \times 60 \times 2.8 \mathrm{~mm}$ and a graphitecoated Bi2Te3 TEG1-1263 with a dimension of $30 \times 30 \times 3.75 \mathrm{~mm}$ in controlled experiment using ten bulbs, eight of which were Eurolite $9005 \mathrm{XB} 65 \mathrm{~W}$ Xenon crystal bulbs, while the other two were sola simulators $400 \mathrm{~W}$ FloraSun bulbs and a load of $21 \Omega$.

Zhou et al. (2016)

Controlled lab. experiment using a direct method.

Sark (2011)

Direct method using the simulation. A mathematical model wa developed for this analysis.

Mohammadnia et al. $(2020 \mathrm{~b})$

Wang et al. (2011)

Control experiment. $65 \mathrm{~W}$ halogen bulb was used as the solar simulator and as the source of irradiance.

Chávez-Urbiola et al. Controlled laboratory experiment using a direct coupling method. (2012)

Lin et al. (2014)

Direct coupling. The TEG was attached to the PV's rear.

Mustofa et al. (2018) Spectrum splitting method was used with a shorter wavelength for the $\mathrm{PV}$, while the longer wavelength for the TEG used a mirror as a medium for the irradiance transmission. A spectrometer software was used for the wavelength measurements.

Yang et al. (2018)

Spectrum splitting was used for this experiment. The TEG was place perpendicular to the PV. The TEG used the irradiance above the spectrum wavelength.

Elsarrag et al. (2015) The experiment was done in a controlled environment using spectrum splitting.

Bjørk and Nielsen

(2018) splitting method. efficiency at a temperature difference of $150^{\circ} \mathrm{C}$ $9.5 \%$ at $0.7 \mathrm{ohms}$ load, while using GaAs, the efficiency is The work was done using the analytical model by adopting the spectrum The PV-TEG efficiency was 4.5\%
The output of PV was $60.5 \mathrm{~W} / \mathrm{m}^{2}$ and the production of TEEG was $0.01 \mathrm{~W} / \mathrm{m}^{2}$. The hybrid PV-TE system achieved an efficiency of $13.2 \%$

Hybrid PV-TEG obtained 9.08\% conversion efficiency, which is substantially improved by $20.6 \%$ and $725.5 \%$, compared to just PV and TEG alone, respectively

The efficiency of the hybrid PV-TEG was $13.98 \%$ at $83^{\circ} \mathrm{CPV}$ temperature and $1000 \mathrm{~W} / \mathrm{m} 2$ irradiance. The PV alone has $10.78 \%$, and the TEG has $3.02 \%$.

The simulation results show an overall system total electric power output of $45.4 \mathrm{~kW}$ at 455 suns.

There was an increase in the efficiency of up to $13 \%$ and the temperature difference of $6.2^{\circ} \mathrm{C}$ at the TEG. DSSC contributed $9.26 \%$, TEG contributed $4.41 \%$, and SSA/TEG contributed $4.6 \%$

The TEG produced an output of $3 \mathrm{~W}$, which contributed $4 \%$

Using the c-si, the PV-TEG efficiency is $11.7 \%$, PV only is $22.94 \%$ at 1.6 ohms load for PV-TEG and $21.9 \%$ for the PV only.

A long wavelength of approximately $800 \mathrm{~nm}$ was released by halogen light for TEG use. The incandescent lamp produces the maximum heat radiation of $54.76 \mathrm{~W} . \mathrm{nm}$, and the lowest heat radiation is $25.65 \mathrm{~W} . \mathrm{nm}$.

The overall hybrid system efficiency was estimated at $18.6 \%$, while it was $17.8 \%$ for the PV alone, using perovskite solar cell.

At a temperature difference of $18 \mathrm{~K}$ under the solar radiation of 1.1 suns, the power output of the TEG was $32 \mathrm{~mW}$ Between 200 and $800 \mathrm{~W} / \mathrm{m} 2$, the split spectrum PV performed better at low irradiance level, up to $700 \mathrm{~W} / \mathrm{m} 2$ which is the average PV.

TEG in a controlled environment using the direct method of coupling

Controlled experiment PV + TEG and simulation

Control experimen

Control experiment simulation

Control experimen

The TEG contributed to addin heat to the solar cell

Controlled environment

Simulation

The TEG is independent of the PV

Analytical method 
Citation: Saleh, U.A., Johar, M.A., Jumaat, S. A, Rejab, M.N., Wan Jamaludin, W.A. (2021) Evaluation of a Hybrid PV-TEG System Configuration for Enhanced Energy Performance: A Review. Int. Journal of Renewable Energy Development, 10(2),385-400, doi: 10.14710/ijred.2021.33917

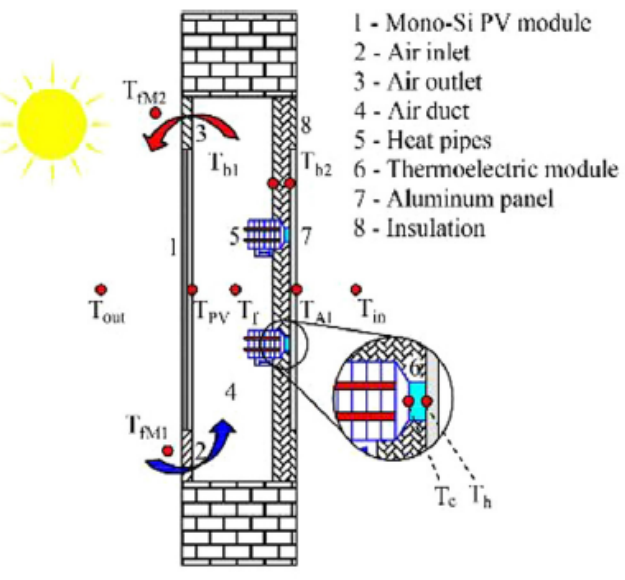

(a) Side vicw of BIPVTE wall

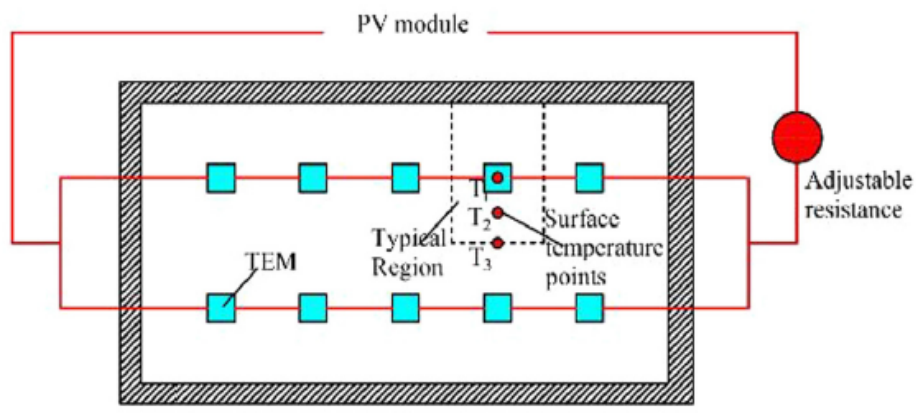

(b) Internal front vicw and system circuit

Fig. 14. System structure of BIPVTE (Luo et al., 2020)

A three-generation network containing a PV cell and TEG, combined with a solar collector using MATLAB software, was implemented in a non-dimensional model (Soltani et $a l$., 2018). The influence of solar irradiance and air temperature on the hybrid system output was examined. In solving eight nonlinear algebraic equations, the authors used iterative Newton-Raphson methods to evaluate the electrical characteristics of the TEG and PV as well as the electrical and thermal efficiencies and thermal and electrical strengths of the system. The effect of solar irradiance and air temperature on the hybrid system's output was examined. The findings indicate improvements in electrical efficiency by positioning the TEG unit and PV cell on the absorber tube's lateral region. $22,714 \mathrm{~W}$ was also attained at a $998 \mathrm{~W} / \mathrm{m}^{2}$ concentration.

A new concept of double zeroes for building envelopes was developed (Luo et al., 2020). The first zero represents zero heat loss or heat gain via the structure envelopes, while the second zero represents the net-zero energy utilisation to attain the first zero. The system was achieved through the coupling of PV, TEG, and the battery. The formed envelope structure in Figure 14 shows that external PV modules were mounted perpendicular to the wall, and the envelope structure had many TE devices coupled to its back and it was mounted such that it faced the tank's internal environment.

The heat flux of the TE module achieved the first zero using power from the PV control; the second zero was attained in a model that predicted control of power flow. Analytical and numerical methods were used for this study and were further validated by the experimental measurements for both winter and summer conditions. The findings of the research showed that this system is highly adaptable to various geographical areas. The system achieved $72-92 \%$ energy savings for winter areas, $88-100 \%$ for mixed-season areas, and $100 \%$ for summer areas. Luo et al. (2020) concluded their study with the creation of net energy utilisation maps. The zero-energy line can be defined as a significant specification for developing "double zero" in the structures' envelopes for various service years.

Zhang et al. (2014) designed a concentrated PV-TEG system that combined a high-performing CIGS with various photovoltaic cells (polymer, polysilicon thin-film, crystalline, silicon and CIGS). Of these combinations, the polysilicon thin-film photovoltaic cell design provided the maximum performance. The combined hybrid system achieved about $8 \%$ performance. Incorporating a selective absorber layer between TEG and PV, Wang et al. (2011) simulated PV-TEG efficiency. This innovative method of integrating a DSSC to form a PV-TEG system improved the system's performance by $13 \%$ with a TEG temperature gradient of $6.2^{\circ} \mathrm{C}$. As the two energy sources are distinct from nature, the PV-TEG hybrid's maximum power point is harder to track than that of the stand-alone PV. Another model was developed by Hashim et al. (2016) to track the MPPT of PV and TEG. The addition of TEG to the PV resulted in a $2 \mathrm{~mW}$ power output reduction due to its thermal resistance, and the $5 \mathrm{~mW}$ TEG power balanced the losses. The MPP of the TEG in this study was based on the optimum length of the TEG unit.

The MPPT controller was attached to the system to maximise the energy output from TEG and PV systems separately. For the PV, the MPPT was employed based on power versus voltage characteristics (Javed et al., 2018). While power versus current characteristics for the TEG. For TE, the MPPT was used based on power versus current TEG characteristics (Amaral et al., 2014). Luo et al. (2020) presented the proposed system's layout. The experimental and simulation analysis of the different PV-TEG system configurations discussed in this review are summarised in Table 1.

\section{Conclusion and Suggestion for Future Works}

One of the technological advancements that can simultaneously harness electrical and thermal energy and increase the overall performance is the hybrid PV-TEG system presented in this work. Simulation and experimental analyses of different hybrid PV-TEG configurations and PV cells, thermoelectric machinery, thermal performance, and electrical efficiency were also presented and discussed. The PV-TEG systems provide a mechanism for broad-spectrum solar radiation harvesting based on the potential of both the PV generators and TEGs for power generation. TEG's combination with a multijunction solar cell tends to produce electricity more 
effectively. Multi-junction solar cells with a maximum energy conversion efficiency of more than $40 \%$ are considered the most efficient, unlike amorphous silicon, polymer solar cells, and crystalline silicon. With concentrated solar radiation, they show suitable performance. The thermal contact resistance between PV and TEG and between TEG and the heat sink reduces the PV-TEG system's efficiency by producing excess PV temperatures. This can be avoided by adding a shingle between the PV and the TEG.

The maximum possible wavelength of PV cells determines the optimum wavelength in a CPV-TEG system with a spectrum splitter. In general, the cold side of the TEG is cooled using various techniques to maintain a large temperature difference in the TEG. By increasing the hot junction temperature, the TEG temperature difference can also be increased. However, only a few PVTEG system configurations use this technique to maintain the temperature gradient. Therefore, PV-TEG hybrid systems seem to have room for future enhancement. These systems have gained recognition in recent times, and noticeable scientific works have aimed at making PV-TEG systems more dependable and feasible. Both experimental and analytical studies on the hybrid system's performance improvement have been technically reviewed in this paper. Despite the abundance of reported research in this domain, little effort has been committed to maintaining the temperature gradient, which is germane. Therefore, further research effort in this area is necessary and recommended. Most of the literature contains studies performed in a controlled atmosphere, and little to no attention has been given to a transient condition. Therefore, experimental work that considers changes in weather conditions should be conducted to compare each of the techniques' strengths and weaknesses. The combination of TEG and PV tends to generate more power, which is essential in dealing with the present power supply challenges.

Further, the concentration ration, the figure of merit, temperature coefficient, and heat transfer coefficient are factors that affect the PV-TEG coupling system's efficiency. To address these technical challenges, the various methods used to investigate these parameters were introduced and examined in this paper. Different approaches from recent studies were also reviewed to enhance the performance of the coupled system. Based on the analysis, the current review presents the following conclusions:

- Increasing the concentration ratio enhances the TEG's efficiency and, thus, increases its contributions to the hybrid system. This, however, is only possible with an effective heat sink.

- A hybrid system comprising a multi-junction PV and Bi2TE3 TEG and with a high concentration ratio results in a high conversion efficiency.

- Effective temperature variations from the PV to the TEG can significantly improve the overall efficiency.

\section{Abbreviations}

AM Air mass

Bi2Te3 Bismuth telluride

CdTe Cadmium telluride

CIGS Copper indium gallium selenide

CoSb3 Copper antimony
CPV-TEG Concentrated photovoltaic-thermoelectric generator DSSC Dye-sensitized solar cell

GaAs Gallium arsenide

GaSb Gallium antimonide

GeTe Germanium telluride

I-V Current-voltage

PCM Phase change material

PV Photovoltaic

PV-TEG Photovoltaic/thermoelectric generator

TEG Thermoelectric generator

SSA Solar selective absorber

\section{Greek symbols}

$\eta \quad$ Efficiency, \%

$\sigma \quad$ Electrical conductivity, $\mathrm{S} / \mathrm{m}$

a Seebeck coefficient, $\mathrm{V} / \mathrm{K}$

к Thermal conductivity, $\mathrm{W} / \mathrm{m} / \mathrm{K}$

\section{Subscripts}

$\mathrm{H} \quad$ Hot side

C Cold side

\section{Nomenclature}

$\begin{array}{ll}\text { A } & \text { Area, m } \\ \text { C } & \text { Concentration ratio } \\ \text { FF } & \text { Fill factor } \\ \text { G } & \text { Solar irradiance, W/m2 } \\ \text { Isc } & \text { Short circuit current, A } \\ \text { Pin } & \text { Input power, W } \\ \text { T } & \text { Temperature, K } \\ \text { Voc } & \text { Open circuit voltage, V } \\ \text { ZT } & \text { Figure of merit }\end{array}$

\section{Acknowledgements}

The research work is partially funded under the FRGS research grant vot number K108 and TIER 1 research grant vot number H114. The authors appreciate the assistance and guidance of the Centre for Atmospheric Research, Price Audu Abubakar University, Anyigba, Kogi, Nigeria, FKEE and FKMP, and Universiti Tun Hussein Onn Malaysia in completing this work.

\section{References}

Acut, R. V. P., Hora, J. A., Gerasta, O. J. L., Zhu, X., \& Dutkiewicz, E. (2019). PV-TEG- WiFi multiple sources design energy harvesting system for WSN application. 2019 4th IEEE International Circuits and Systems Symposium, ICSyS 2019 ,

4-8. https://doi.org/10.1109/ICSyS47076.2019.8982439

Akashah, W., Jamaludin, W., \& Johar, M. A. (2019). Temperature analysis of concrete shingle thermal behavior under feasibility study of concrete shingle as renewable energy. 1-

Al Musleh, M., Topriska, E. V., Jenkins, D., \& Owens, E. (2020). Thermoelectric generator characterisation at the extra-lowtemperature difference for building applications in scorching climates: Experimental and numerical study. Energy and Buildings, $225, \quad 110285$. https://doi.org/10.1016/j.enbuild.2020.110285

Aljaghtham, M., \& Celik, E. (2020). Design optimisation of oil pan thermoelectric generator to recover waste heat from internal combustion engines. Energy, 200, 117547. 
Citation: Saleh, U.A., Johar, M.A., Jumaat, S. A, Rejab, M.N., Wan Jamaludin, W.A. (2021) Evaluation of a Hybrid PV-TEG System Configuration for Enhanced Energy Performance: A Review. Int. Journal of Renewable Energy Development, 10(2),385-400, doi: 10.14710/ijred.2021.33917

P a g e | 398

https://doi.org/10.1016/j.energy.2020.117547

Amaral, C., Brandão, C., Sempels, É. V., \& Lesage, F. J. (2014). Thermoelectric power enhancement through flow impedance for fixed thermal input conditions. Journal of Power Sources, 272 , $672-680$. https://doi.org/10.1016/j.jpowsour.2014.09.003

Aravind, B., Khandelwal, B., Ramakrishna, P. A., \& Kumar, S. (2020). Towards the development of a high power density, high efficiency, micropower generator. Applied Energy, 261 (December 2019), 114386. https://doi.org/10.1016/j.apenergy.2019.114386

Babu, C., \& Ponnambalam, P. (2017). The role of thermoelectric generators in the hybrid PV/T systems: A review. Energy Conversion and Management, 151(August), 368-385. https://doi.org/10.1016/j.enconman.2017.08.060

Babu, C., \& Ponnambalam, P. (2018). The theoretical performance evaluation of hybrid PV-TEG system. Energy Conversion and Management, 173(August), 450-460. https://doi.org/10.1016/j.enconman.2018.07.104

Bjørk, R., \& Nielsen, K. K. (2018). The maximum theoretical performance of unconcentrated solar photovoltaic and thermoelectric generator systems. Energy Conversion and Management, 156(September 2017), 264-268. https://doi.org/10.1016/j.enconman.2017.11.009

Cai, Y., Wang, L., Wang, W. W., Liu, D., \& Zhao, F. Y. (2020). Solar energy harvesting potential of a photovoltaic-thermoelectric cooling and power generation system: Bidirectional modelling and performance optimisation. Journal of Cleaner Production, 254 , 120150. https://doi.org/10.1016/j.jclepro.2020.120150

Cai, Y., Wang, W. W., Liu, C. W., Ding, W. T., Liu, D., \& Zhao, F. Y. (2020). Performance evaluation of a thermoelectric ventilation system driven by the concentrated photovoltaic, thermoelectric generators for green building operations. Renewable Energy, 147, 1565-1583. https://doi.org/10.1016/j.renene.2019.09.090

Cai, Y., Wang, Y., Liu, D., \& Zhao, F. Y. (2019). Thermoelectric cooling technology applied in electronic devices: An updated review of the parametric investigations and model developments. Applied Thermal Engineering, 148(April 2018),

238-255. https://doi.org/10.1016/j.applthermaleng.2018.11.014

Chávez-Urbiola, E. A., Vorobiev, Y. V., \& Bulat, L. P. (2012). Solar hybrid systems with thermoelectric generators. Solar Energy, $\quad$ 86(1), 369-378. https://doi.org/10.1016/j.solener.2011.10.020

Coskun, C., Toygar, U., Sarpdag, O., \& Oktay, Z. (2017). Sensitivity analysis of implicit correlations for photovoltaic module temperature: A review. Journal of Cleaner Production, 164, 1474-1485. https://doi.org/10.1016/j.jclepro.2017.07.080

Cui, T., Xuan, Y., \& Li, Q. (2016). Design of a novel concentrating photovoltaic-thermoelectric system incorporated with phase change materials. Energy Conversion and Management, 112, 49-60. https://doi.org/10.1016/j.enconman.2016.01.008

Daghigh, R., \& Khaledian, Y. (2018). A novel photovoltaic/thermoelectric collector combined with a dual Evaporator vapour compression system. Energy Conversion and Management, 158(October 2017), 156-167. https://doi.org/10.1016/j.enconman.2017.12.067

Dallan, B. S., Schumann, J., \& Lesage, F. J. (2015). Performance evaluation of a photoelectric-thermoelectric cogeneration hybrid system. Solar Energy, 118, 276-285. https://doi.org/10.1016/j.solener.2015.05.034

Elsarrag, E., Pernau, H., Heuer, J., Roshan, N., Alhorr, Y., \& Bartholomé, K. (2015). Spectrum splitting for efficient utilisation of solar radiation: a novel photovoltaicthermoelectric power generation system. Renewables: Wind, Water, and Solar, 2(1). https://doi.org/10.1186/s40807-0150016-y

Fisac, M., Villasevil, F. X., \& López, A. M. (2014). High-efficiency photovoltaic technology, including thermoelectric generation. Journal of Power Sources, 252, 264-269. https://doi.org/10.1016/j.jpowsour.2013.11.121

Goldsmid, H. J., Giutronich, J. E., \& Kaila, M. M. (1980). Solar thermoelectric generation using bismuth telluride alloys. Solar Energy, 24(5), 435-440. https://doi.org/10.1016/0038092X(80)90311-4

Grubišić-Čabo, F., Nižetić, S., \& Marco, T. G. (2016). Photovoltaic panels: A review of the cooling techniques. Transactions of Famine, 40(June), 63-74.

Gu, W., Ma, T., Song, A., Li, M., \& Shen, L. (2019). Mathematical modelling and performance evaluation of a hybrid photovoltaic-thermoelectric system. Energy Conversion and Management 198(July),

111800. https://doi.org/10.1016/j.enconman.2019.111800

Hajji, M., Labrim, H., Benaissa, M., Laazizi, A., Ez-Zahraouy, H., Ntsoenzok, E., Meot, J., \& Benyoussef, A. (2017). Photovoltaic and thermoelectric indirect coupling for maximum solar energy exploitation. Energy Conversion and Management, 136 , https://doi.org/10.1016/j.enconman.2016.12.088

Hamid Elsheikh, M., Shnawah, D. A., Sabri, M. F. M., Said, S. B. M., Haji Hassan, M., Ali Bashir, M. B., \& Mohamad, M. (2014). A review on thermoelectric renewable energy: Principle parameters that affect their performance. Renewable and Sustainable Energy Reviews, 30, 337-355. https://doi.org/10.1016/j.rser.2013.10.027

Hashim, H., Bomphrey, J. J., \& Min, G. (2016). Model for geometry optimisation of thermoelectric devices in a hybrid PV/TE system. Renewable Energy, 87, 458-463. https://doi.org/10.1016/j.renene.2015.10.029

Hoang, T. V., Ifaei, P., Nam, K., Rashidi, J., Hwangbo, S., Oh, J. M., \& Yoo, C. K. (2018). Optimal management of a hybrid renewable energy system coupled with a membrane bioreactor using enviro-economic and power pinch analyses for sustainable climate change adaption. Sustainability (Switzerland), 11(1). https://doi.org/10.3390/su11010066

Huen, P., \& Daoud, W. A. (2017a). Advances in hybrid solar photovoltaic and thermoelectric generators. Renewable and Sustainable Energy Reviews, 72(September), 1295-1302. https://doi.org/10.1016/j.rser.2016.10.042

Huen, P., \& Daoud, W. A. (2017b). Advances in hybrid solar photovoltaic and thermoelectric generators. Renewable and Sustainable Energy Reviews, 72(October), 1295-1302. https://doi.org/10.1016/j.rser.2016.10.042

Jatoi, A. R., Samo, S. R., \& Jakhrani, A. Q. (2018). Influence of temperature on electrical characteristics of different photovoltaic module technologies. International Journal of Renewable Energy Development, 7(2), 85-91. https://doi.org/10.14710/ijred.7.2.85-91

Javed, K., Ashfaq, H., \& Singh, R. (2018). An improved MPPT algorithm to minimise transient and steady-state oscillation conditions for small SPV systems. International Journal of Renewable Energy Development, 7(3), 191-197. https://doi.org/10.14710/ijred.7.3.191-197

Johar, M. A., Yahaya, Z., Marwah, O. M. F., Jamaludin, W. A. W., \& Ribuan, M. N. (2017). Feasibility study of thermal electric generator configurations as renewable energy sources. Journal of Physics: Conference Series, 914(1). https://doi.org/10.1088/1742-6596/914/1/012024

Ju, X., Wang, Z., Flamant, G., Li, P., \& Zhao, W. (2012). Numerical analysis and optimisation of a spectrum splitting concentration photovoltaic-thermoelectric hybrid system. Solar Energy, 86(6), 1941-1954. https://doi.org/10.1016/j.solener.2012.02.024

Kabir, E., Kumar, P., Kumar, S., Adelodun, A. A., \& Kim, K. H. (2018). Solar energy: Potential and prospects. Renewable and Sustainable Energy Reviews, 82(August 2017), 894-900. https://doi.org/10.1016/j.rser.2017.09.094

Karami Lakeh, H., Kaatuzian, H., \& Hosseini, R. (2019). A parametrical study on the photo-electro-thermal 
performance of an integrated thermoelectric-photovoltaic cell. Renewable Energy, 138, 542-550. https://doi.org/10.1016/j.renene.2019.01.094

Keser, O. F., Idare, B., Bulat, B., \& Okan, A. (2019). The usability of PV-TEG hybrid systems on space platforms. Proceedings of 9th International Conference on Recent Advances in Space Technologies, RAST 2019, 109-115. https://doi.org/10.1109/RAST.2019.8767785

Khanmohammadi, S., Musharavati, F., Kizilkan, O., \& Duc Nguyen, D. (2020). Proposal of a new parabolic solar collector assisted power-refrigeration system integrated with a thermoelectric generator using $3 \mathrm{E}$ analyses: Energy, exergy, and energy-economic. Energy Conversion and Management, 220 (June), 113055. https://doi.org/10.1016/j.enconman.2020.113055

Kil, T. H., Kim, S., Jeong, D. H., Geum, D. M., Lee, S., Jung, S. J., Kim, S., Park, C., Kim, J. S., Baik, J. M., Lee, K. S., Kim, C. Z., Choi, W. J., \& Baek, S. H. (2017). A highly-efficient, concentrating-photovoltaic/thermoelectric hybrid generator. Nano Energy, $37, \quad 242-247$. https://doi.org/10.1016/j.nanoen.2017.05.023

Krishna Kumar, T. S., Anil Kumar, S., Kodanda Ram, K., Raj Goli, K., \& Siva Prasad, V. (2020). Analysis of thermoelectric generators in automobile applications. Materials Today: Proceedings,

https://doi.org/10.1016/j.matpr.2020.08.081

Kusch-Brandt. (, 2019). Urban renewable energy on the upswing: A spotlight on renewable energy in cities in REN21's "Renewables 2019 Global Status Report." In REN21 RENEWABLES NOW (Vol. 8, Issue 3). https://doi.org/10.3390/resources8030139

Lamba, R., \& Kaushik, S. C. (2016). Modelling and performance analysis of a concentrated photovoltaic-thermoelectric hybrid power generation system. Energy Conversion and Management, 115 , 288-298. https://doi.org/10.1016/j.enconman.2016.02.061

Lamba, R., \& Kaushik, S. C. (2018). Solar driven concentrated photovoltaic-thermoelectric hybrid system: Numerical analysis and optimisation. Energy Conversion and Management, $\quad$ 170(January), 34-49. https://doi.org/10.1016/j.enconman.2018.05.048

Li, G., Shittu, S., Ma, X., \& Zhao, X. (2019). Comparative analysis of thermoelectric elements optimum geometry between photovoltaic-thermoelectric and solar thermoelectric. Energy, 171, 599-610. https://doi.org/10.1016/j.energy.2019.01.057

Li, G., Shittu, S., Zhou, K., Zhao, X., \& Ma, X. (2019). Preliminary experiment on a novel photovoltaic-thermoelectric system in summer. Energy, 188, 116041. https://doi.org/10.1016/j.energy.2019.116041

Li, G., Zhao, X., \& Ji, J. (2016). Conceptual development of a novel photovoltaic-thermoelectric system and preliminary economic analysis. Energy Conversion and Management, 126 , https://doi.org/10.1016/j.enconman.2016.08.074

935-943.

Li, J. F., Liu, W. S., Zhao, L. D., \& Zhou, M. (2010). Highperformance nanostructured thermoelectric materials. $N P G$ Asia Materials, 2(4), 152-158. https://doi.org/10.1038/asiamat.2010.138

Lin, W., Shih, T. M., Zheng, J. C., Zhang, Y., \& Chen, J. (2014). Coupling of temperatures and power outputs in hybrid photovoltaic and thermoelectric modules. International Journal of Heat and Mass Transfer, 74, 121-127. https://doi.org/10.1016/j.ijheatmasstransfer.2014.02.075

Lineykin, S., Sitbon, M., \& Kuperman, A. (2020). Design and optimisation of low-temperature gradient thermoelectric harvester for wireless sensor network node on water pipelines. Applied Energy, November, 116240. https://doi.org/10.1016/j.apenergy.2020.116240

Liu, J., Tang, H., Zhang, D., Jiao, S., Zhou, Z., Zhang, Z., Ling, J., \& Zuo, J. (2020). Performance evaluation of the hybrid photovoltaic-thermoelectric system with light and heat management. Energy, 211,

https://doi.org/10.1016/j.energy.2020.118618

118618.

Looi, K. K., Baheta, A. T., \& Habib, K. (2020). Investigation of photovoltaic, thermoelectric air-conditioning system for room application under tropical climate. Journal of Mechanical Science and Technology, 34(5), 2199-2205. https://doi.org/10.1007/s12206-020-0441-8

Lund, A., Tian, Y., Darabi, S., \& Müller, C. (2020). A polymerbased textile thermoelectric generator for wearable energy harvesting. Journal of Power Sources, 480(September), 228836. https://doi.org/10.1016/j.jpowsour.2020.228836

Luo, Y., Zhang, L., Liu, Z., Yu, J., Xu, X., \& Su, X. (2020). Towards net-zero energy building: The application potential and adaptability of a photovoltaic-thermoelectric-battery wall system. Applied Energy, 258(October 2019), 114066. https://doi.org/10.1016/j.apenergy.2019.114066

Mahmoudinezhad, S., Rezania, A., Cotfas, D. T., Cotfas, P. A., \& Rosendahl, L. A. (2018). Experimental and numerical investigation of hybrid concentrated photovoltaic Thermoelectric module under low solar concentration. Energy, 159, 1123-1131. https://doi.org/10.1016/j.energy.2018.06.181

Makki, A., Omer, S., Su, Y., \& Sabir, H. (2016). Numerical investigation of heat pipe-based photovoltaic-thermoelectric generator (HP-PV/TEG) hybrid system. Energy Conversion and Management, 112, 274-287. https://doi.org/10.1016/j.enconman.2015.12.069

Mirzakhanyan, A. (2005). Economic and social development. The Armenians: Past and Present in the Making of National Identity, 3(June), 196-210. https://doi.org/10.4324/9780203004937

Mohammad, A. N. M., Radzi, M. A. M., Azis, N., Shafie, S., \& Zainuri, M. A. A. M. (2020). A novel hybrid approach for maximising the extracted photovoltaic power under complex partial shading conditions. Applied Sciences (Switzerland), 12(14), 1-24. https://doi.org/10.3390/su12145786

Mohammadnia, A., Rezania, A., Ziapour, B. M., Sedaghati, F., \& Rosendahl, L. (2020a). Hybrid energy harvesting system to maximise power generation from solar energy. Energy Conversion and Management, 205(December 2019), 112352. https://doi.org/10.1016/j.enconman.2019.112352

Mohammadnia, A., Rezania, A., Ziapour, B. M., Sedaghati, F., \& Rosendahl, L. (2020b). Hybrid energy harvesting system to maximise power generation from solar energy. Energy Conversion and Management, 205(November 2019), 112352. https://doi.org/10.1016/j.enconman.2019.112352

Motiei, P., Yaghoubi, M., \& GoshtasbiRad, E. (2019). Transient simulation of a hybrid photovoltaic-thermoelectric system using a phase change material. Sustainable Energy Technologies and Assessments, 34(October 2018), 200-213. https://doi.org/10.1016/j.seta.2019.05.004

Mustofa, Djafar, Z., Syafaruddin, \& Piarah, W. H. (2018). A new hybrid of a photovoltaic-thermoelectric generator with hot mirror as spectrum splitter. Journal of Physical Science, 29, 63-75. https://doi.org/10.21315/jps2018.29.s2.6

Nižetić, S., Marinić-Kragić, I., Grubišić-Čabo, F., Papadopoulos, A. M., \& Xie, G. (2020). Analysis of novel passive cooling strategies for free-standing silicon photovoltaic panels. Journal of Thermal Analysis and Calorimetry. https://doi.org/10.1007/s10973-020-09410-7

Patel, V. R., \& Patel, M. C. (2020). Automobile waste heat recovery system using thermoelectric generator. Journal of Science and Technology, 5(3), 58-61. https://doi.org/10.46243/jst.2020.v5.i3.pp58-61

Premkumar, M., Kumar, C., \& Sowmya, R. (2020). Mathematical modelling of solar photovoltaic cell/panel/array based on the physical parameters from the manufacturer's datasheet. International Journal of Renewable Energy Development, 9(1), 7-22. https://doi.org/10.14710/ijred.9.1.7-22

Rejeb, O., Shittu, S., Ghenai, C., Li, G., Zhao, X., \& Bettayeb, M. (2020). Optimisation and performance analysis of a concentrated solar photovoltaic-thermoelectric (CPV-TE) 
Citation: Saleh, U.A., Johar, M.A., Jumaat, S. A, Rejab, M.N., Wan Jamaludin, W.A. (2021) Evaluation of a Hybrid PV-TEG System Configuration for Enhanced Energy Performance: A Review. Int. Journal of Renewable Energy Development, 10(2),385-400, doi: 10.14710/ijred.2021.33917

P a g e 1400

hybrid system. Renewable Energy, 152, 1342-1353. https://doi.org/10.1016/j.renene.2020.02.007

Rezania, A., \& Rosendahl, L. A. (2017). Feasibility and parametric evaluation of hybrid concentrated photovoltaicthermoelectric system. Applied Energy, 187, 380-389. https://doi.org/10.1016/j.apenergy.2016.11.064

Rodrigo, P. M., Valera, A., Fernández, E. F., \& Almonacid, F. M. (2019). Performance and economic limits of passively cooled hybrid thermoelectric generator-concentrator photovoltaic modules. Applied Energy, 238(October 2018), 1150-1162. https://doi.org/10.1016/j.apenergy.2019.01.132

Rostamzadeh, H., \& Nourani, P. (2019). Investigating potential benefits of a salinity gradient solar pond for ejector refrigeration cycle coupled with a thermoelectric generator. Energy, 172, 675-690. https://doi.org/10.1016/j.energy.2019.01.167

Sahin, A. Z., Ismaila, K. G., Yilbas, B. S., \& Al-Sharafi, A. (2020). A review of the performance of photovoltaic/thermoelectric hybrid generators. International Journal of Energy Research, December 2019, 1-30. https://doi.org/10.1002/er.5139

Sark, W. G. J. H. M. VA. (2011). Feasibility of photovoltaic Thermoelectric hybrid modules. Applied Energy, 88(8), 2785-2790. https://doi.org/10.1016/j.apenergy.2011.02.008

Shatar, N. M., Rahman, M. A. A., Muhtazaruddin, M. N., Salim, S. A. Z. S., Singh, B., Muhammad-Sukki, F., Bani, N. A., Saudi, A. S. M., \& Ardila-Rey, J. A. (2019). Performance evaluation of unconcentrated photovoltaic-thermoelectric generator hybrid system under tropical climate. Sustainability (Switzerland), 11(22). https://doi.org/10.3390/su11226192

Shittu, S., Li, G., Akhlaghi, Y. G., Ma, X., Zhao, X., \& Ayodele, E. (2019). Advancements in thermoelectric generators for enhanced hybrid photovoltaic system performance. Renewable and Sustainable Energy Reviews, 109(March), 24-54. https://doi.org/10.1016/j.rser.2019.04.023

Shittu, S., Li, G., Zhao, X., Akhlaghi, Y. G., Ma, X., \& Yu, M. (2019). Comparative study of a concentrated photovoltaicthermoelectric system with and without flat plate heat pipe. Energy Conversion and Management, 193(February), 1-14. https://doi.org/10.1016/j.enconman.2019.04.055

Singh, S., Ibeagwu, O. I., \& Lamba, R. (2018). Thermodynamic evaluation of irreversibility and optimum performance of a concentrated PV-TEG cogenerated hybrid system. Solar Energy, 170(January), 896-905. https://doi.org/10.1016/j.solener.2018.06.034

Soltani, S., Kasaeian, A., Sokhansefat, T., \& Shafii, M. B. (2018). Performance investigation of a hybrid photovoltaic/thermoelectric system integrated with parabolic trough collector. Energy Conversion and Management, 159(September 2017), 371-380. https://doi.org/10.1016/j.enconman.2017.12.091

Wan Jamaludin, W. A., Johar, M. A., Faizan Marwah, O. M., \& Amin, A. M. (2020). Evaluation of the potential of renewable thermal energy from shingles using a thermoelectric generator (TEG) for residential use application. Journal of Advanced Research in Fluid Mechanics and Thermal Sciences, $70(2)$ https://doi.org/10.37934/ARFMTS.70.2.5058

Wang, N., Han, L., He, H., Park, N. H., \& Koumoto, K. (2011). A novel high-performance photovoltaic-thermoelectric hybrid device. Energy and Environmental Science, 4(9), 3676-3679. https://doi.org/10.1039/c1ee01646f

Wang, X., Tang, D. S. K., \& Henshaw, P. (2020). Mutation particle swarm optimisation (M-PSO) of a thermoelectric generator in a multi-variable space. Energy Conversion and
Management,

224(September),

113387.

https://doi.org/10.1016/j.enconman.2020.113387

Wu, S. Y., Zhang, Y. C., Xiao, L., \& Shen, Z. G. (2018). Performance comparison investigation on the solar photovoltaicthermoelectric generation and solar photovoltaicthermoelectric cooling hybrid systems under different conditions. International Journal of Sustainable Energy, $37(6)$,

$533-548$. https://doi.org/10.1080/14786451.2017.1345906

Xu, L., Xiong, Y., Mei, A., Hu, Y., Rong, Y., Zhou, Y., Hu, B., \& Han, H. (2018). Efficient Perovskite PhotovoltaicThermoelectric Hybrid Device. Advanced Energy Materials, 8(13), 1-5. https://doi.org/10.1002/aenm.201702937

Yang, Z., Li, W., Chen, X., Su, S., Lin, G., \& Chen, J. (2018). Maximum efficiency and parametric optimum selection of a concentrated solar spectrum splitting photovoltaic cellthermoelectric generator system. Energy Conversion and Management, 174(April), 65-71. https://doi.org/10.1016/j.enconman.2018.08.038

Yin, E., \& Li, Q. (2020). Unsteady-state performance comparison of the tandem photovoltaic-thermoelectric hybrid system and a conventional photovoltaic system. Solar Energy, 211(September), https://doi.org/10.1016/j.solener.2020.09.049

Yin, E., Li, Q., Li, D., \& Xuan, Y. (2019). Experimental investigation on the effects of thermal resistances on a photovoltaic-thermoelectric system integrated with phase change materials. Energy, 169, 172-185. https://doi.org/10.1016/j.energy.2018.12.035

Yin, E., Li, Q., \& Xuan, Y. (2018a). One-day performance evaluation of the photovoltaic-thermoelectric hybrid system. Energy, 143, 337-346. https://doi.org/10.1016/j.energy.2017.11.011

Yin, E., Li, Q., \& Xuan, Y. (2018b). Optimal design method for concentrating photovoltaic-thermoelectric hybrid system. Applied Energy, 226(January), 320-329. https://doi.org/10.1016/j.apenergy.2018.05.127

Yin, E., Li, Q., \& Xuan, Y. (2019). Experimental optimisation of operating conditions for concentrating photovoltaicthermoelectric hybrid system. Journal of Power Sources, 422(February) https://doi.org/10.1016/j.jpowsour.2019.03.034

Yin, E., Li, Q., \& Xuan, Y. (2020). Feasibility analysis of a tandem photovoltaic-thermoelectric hybrid system under solar concentration. Renewable Energy, 162, 1828-1841. https://doi.org/10.1016/j.renene.2020.10.006

Yuan, Z., Liu, K., Xu, Z., Wang, H., Liu, Y., \& Tang, X. (2020). Development of micro-radioisotope thermoelectric power supply for deep space exploration distributed wireless sensor network. Advances in Astronautics Science and Technology. https://doi.org/10.1007/s42423-020-00062-1

Zhang, Jia, Zhai, H., Wu, Z., Wang, Y., \& Xie, H. (2020). Experimental investigation of novel integrated photovoltaicthermoelectric hybrid devices with enhanced performance. Solar Energy Materials and Solar Cells, 215(June), 110666. https://doi.org/10.1016/j.solmat.2020.110666

Zhang, Jin, Xuan, Y., \& Yang, L. (2014). Performance estimation of photovoltaic-thermoelectric hybrid systems. Energy, 78, 895-903. https://doi.org/10.1016/j.energy.2014.10.087

Zhou, Z., Yang, J., Jiang, Q., Li, W., Luo, Y., Hou, Y., Zhou, S., \& Li, X. (2016). Considerable improvement of device performance by a synergistic effect of Photovoltaics and thermoelectrics. Nano Energy, 22, 120-128. https://doi.org/10.1016/j.nanoen.2016.02.018 